\title{
Executive Remuneration Principles, Practices and Processes: An Institutional Logics Perspective.
}

\author{
Neil A. Crombie \\ School of Business and Economics, \\ University of Canterbury, \\ Private Bag 4800, \\ Christchurch 8041, New Zealand \\ Email: neil.crombie@ canterbury.ac.nz
}

Note: This article has been published in the International Journal of Corporate Governance by Inderscience. The citation is: Crombie, N.A. (2015) 'Executive remuneration principles, practices and processes: an institutional logics perspective', International Journal of Corporate Governance, Vol. 6, Nos. 2/3/4, pp.98-140, http://doi.org/10.1504/IJCG.2015.074693.

\begin{abstract}
Agency Logic assumes that executives are greedy and opportunistic, which implies that monetary incentives are necessary to ensure they act in the best interests of shareholders; whereas Corporate Logic assumes that executives are trustworthy professionals, which implies that they will act in the best interests of shareholders irrespective of the use of monetary incentives. Prior qualitative research on executive remuneration is reviewed in this paper in order to ascertain how these Logics influence the decision-making of remuneration committees. Given that Agency Logic and Corporate Logic are opposites, there is a tension between the remuneration principles of pay-for-performance and competitive pay. However, Corporate Logic trumps Agency Logic as remuneration committees prioritise competitive pay ahead of other principles, so that talented executives will be retained. The paper also
\end{abstract}


discusses a range of other remuneration principles and practices as well as the remuneration processes that have diffused both Logics amongst remuneration committees.

Keywords: Corporate Governance; Executive Compensation; Compensation Committees; Institutional Theory; Institutional Logics Perspective.

\section{Introduction}

This paper presents an inventory of remuneration principles, which are inductively derived from prior qualitative research on executive remuneration. Remuneration principles are systems of belief and reasoning which individuals and organisations use to make, interpret and justify remuneration decisions. These often take the form of idioms such as pay-forperformance and pay competitively (Bender, 2004). Drawing on an institutional logics perspective - which is a branch of institutional theory - this paper asserts that beliefs, concepts, theories, values, etc. can become powerful forces that shape society (Thornton, Ocasio and Lounsbury, 2012; Zajac and Westphal, 2004). From an institutional logics perspective (Thornton et al., 2012), remuneration principles constrain and enable organisational decision-making and reporting by defining what are and are not legitimate actions. Boards of directors and remuneration committees use remuneration principles to frame their decision-making in order to fulfil their conformance and performance roles. Further, remuneration principles legitimise remuneration practices (e.g. stock option plans) and are diffused through common remuneration processes (e.g. remuneration consultants). However, as remuneration principles are open to interpretation, it is possible for companies to justify the same remuneration practices with different remuneration principles and to justify different practices with the same principles. 
By reinterpreting prior qualitative research on executive remuneration, this paper makes two significant contributions to knowledge. First, the concept of the remuneration principle is introduced and critiqued. Remuneration principles are a common feature in the regulation and practice of corporate governance, but have not featured in academic literature to date. Underpinning each corporate governance code of best practice is a set of principles that frame recommendations (e.g. ASX Corporate Governance Council, Australia, 2014; Business Roundtable, USA, 2012; Financial Reporting Council, UK, 2014). Similarly, remuneration practices are often justified using what this paper defines as remuneration principles (Point and Tyson, 2006; Wade, Porac, Pollack, 1997; Zajac and Westphal, 1995). Instead of studying corporate governance codes and corporate annual reports (e.g. Point and Tyson, 2006), this paper reinterprets the beliefs and opinions of executives, directors, remuneration consultants, and others as presented in prior qualitative research (45 studies are reviewed, see Appendix A). In doing so, this paper identifies 14 remuneration principles and then shows how these principles influence remuneration decision-making and how these principles have been diffused and institutionalised.

Second, Zajac and Westphal's (2004) theorisation of Agency Logic and Corporate Logic is extended by demonstrating the link between these Logics and various remuneration principles and practices. Corporate Logic assumes that executives are trustworthy professionals and non-executive directors act as advisors, and both parties willing act in the best interests of shareholders; whereas, Agency Logic assumes that executives are self-interested agents and non-executive directors act as a constraint on the opportunistic behaviour of executives, using monitoring and incentive mechanisms to ensure that executives act in the best interests of shareholders (Lok, 2010; Zajac and Westphal, 2004). Corporate Logic is linked to managerialist theory (Chandler, 1962), resource dependence theory (Pfeffer and Salancik, 
1978) and stewardship theory (Davis, Schoorman and Donaldson, 1997); whereas Agency Logic is linked to agency theory (Jensen and Meckling, 1976) and managerial hegemony/power theory (Bebchuk and Fried, 2004; Mace, 1971). However, these Logics are under-theorised with respect to executive remuneration. Zajac and Westphal (2004, p.436) only put forward that Corporate Logic implies boards (or remuneration committees) should "[u]se salary and other rewards to attract and retain scarce management talent"; whereas, Agency Logic implies boards should "[u]se incentives to align management and shareholder interests". Prior studies have not examined these Logics' implications for executive remuneration. This paper asserts that there are two sets of remuneration principles and practices with one constituting Agency Logic and the other constituting Corporate Logic.

The remainder of this paper is organised as follows. Traditional research on executive remuneration is briefly reviewed and critiqued in the second section. The main criticism is that boardroom decision-making is treated as a "black box". The third section discusses an institutional logics perspective on corporate governance, which provides a theoretical framework for unpacking the "black box". Agency Logic and Corporate Logic represent opposing beliefs about how corporate governance is and should be practiced. The fourth section presents an inventory of remuneration principles. Drawing on an institutional logics perspective, how remuneration committees use the remuneration principles to make decisions is discussed. The fifth section examines the typical remuneration package for executives and how it is justified. This package can be justified using Agency Logic and/or Corporate Logic. A framework for the diffusion and institutionalisation of the remuneration principles and Logics is presented in the penultimate section. Throughout these sections future research opportunities are highlighted. In the final section, theoretical and practical implications of the remuneration principles and Logics are elucidated. 


\section{Traditional Research on Executive Remuneration}

There has been a plethora of research on executive remuneration (Murphy, 2013). Agency theory - a mathematised version of Agency Logic (Zajac and Westphal, 2004) - has underpinned most of this research, where it has been argued that executive remuneration should be tied to firm performance, particularly shareholder returns (Dalton, Hitt, Certo and Dalton, 2007; Gerhart, Rynes and Fulmer, 2009). This will ensure, in an ideal world, that resources are managed effectively and efficiently at both the organisational and societal levels (Kaen, Kaufman and Zacharias, 1988). Meta-analyses have found mixed results with the general consensus being that there is a significant but weak relationship between CEO pay and firm performance (Dalton, Daily, Certo and Roengpitya, 2003; van Essen, Heugens, Otten and van Oosterhout, 2012; van Essen, Otten and Carberry, 2015; Rost and Osterloh, 2009; Tosi, Werner, Katz and Gomez-Mejia, 2000). Gerhart and Fang (2014, p.50) conclude that, "...it is difficult to envision how individuals, companies, and economies would fare better, on average, by significantly diminishing the role of PFIP [pay for individual performance] in organizations." Despite the empirical evidence being less than fully supportive of Agency Theory and the efficacy of incentive schemes, Gerhart and Fang's sentiment has been commonplace in the accounting, economics, finance, and management literature on executive remuneration for at least forty years.

There are at least two significant problems with traditional research on executive remuneration. Firstly, many scholars appear to blindly follow agency theory with only superficial consideration given to alternative theories. This is best observed in the many reformulations of agency theory as scholars have attempted to build complexity and exceptions into agency theory in order to defend it against criticism and incorporate empirical 
evidence that is suggestive of alternative explanations (e.g. see Lan and Heracleous, 2010; Lubatkin, Lane, Collin and Very, 2007; Pepper and Gore, 2015; Wiseman, Cuevas-Rodriguez and Gomez-Mejia, 2012). Alternatives such as expectancy theory, institutional theory, labour market theory, social comparison theory, stakeholder theory, stewardship theory, etc. are under-researched relative to agency theory (for reviews, see Gomez-Mejia, Berrone and Franco-Santos, 2010, Chapter 4; Otten, 2007). Ferraro, Pfeffer and Sutton (2005, p.8) argued that, "theories can "win" in the marketplace for ideas, independent of their empirical validity..." Ghoshal (2005) argued that this has occurred in the case of agency theory and that agency theory had become a self-fulfilling prophecy as business schools disseminated its assumptions and prescriptions among business leaders. Further, Pirson and Lawrence (2010) called for a paradigm shift in business research from economism (exemplified by agency theory) towards humanism. Despite criticism, agency theory remains firmly entrenched in academic and business discourse (Dobbin and Jung, 2010).

Secondly, most scholars investigating the effects of how and how much executives are paid on firm performance have overlooked the pay-setting process (i.e. the work of the remuneration committee and remuneration consultants), treating it as a black box. The emphasis has been on finding universal truths. This is exemplified by Jensen and Murphy's (1990, p.225) often cited study, which found that "CEO wealth changes $\$ 3.25$ for every $\$ 1,000$ change in shareholder wealth." Traditionally, scholars have used proxies - variables that are easy to measure - to study behaviour and processes. For example, Cremers and Grinstein (2014) study the extent to which CEOs are paid for luck and/or skill by comparing firm returns to industry returns, rather than assessing the actions of CEOs and the circumstances which they faced. Similarly, Haynes, Campbell and Hitt (2014) measured CEO greed using financial outcomes, rather than assessing the psychological profile of CEOs. 
Treating the pay-setting process as a black box severely limits what can be learnt about organisational behaviour. However, there is a small but growing body of research that is studying the black box (e.g. Adams and Gianneti, 2012; Graham, Harvey and Puri, 2013). Such research uses surveys to understand the psychology and behaviour of CEOs, directors and others, and then relates this to their pay and performance.

\section{An Institutional Logics Perspective on Corporate Governance}

Drawing on institutional theory, an institutional logics perspective asserts that beliefs, norms, rules, values, etc. enable and constrain people's behaviour and when an institutional logic dominates part of society, people's behaviour becomes homogenous (Thornton et al., 2012). From this perspective, there is reason to think that Agency Logic - which encompasses agency theory - has had a homogenising effect on organisations, particularly executive remuneration policies and practices. For instance, in a study of Harvard Business Review articles, Spector and Spital (2011) found that agency theory is built on an ideology, not empirical evidence that favours managerial incentives. Advancing this ideology was "Arch Patton, a McKinsey Consultant and the most published author in the Harvard Business Review during the 1950s” (p.315). There was much financial gain for consultants and business leaders as incentive schemes became widely adopted. They concluded that, "Agency theory, which is presented as a rational and legitimate argument in favor of such [executive] bonuses, fails to address the historical context in which bonuses actually took root in corporate America" (p.315). If Agency Logic is indeed an ideology or beliefs system that permeates academic and business discourse, then it may be that remuneration committees draw on Agency Logic to both guide and justify their decision-making. However, there may also be other Logics that influence their decision-making. 
Corporate Logic, Agency Logic and Stakeholder Logic are the most commonly studied institutional logics of corporate governance, although these have not always been consistently named. Corporate Logic is also known as Managerial Capitalism (Green, Babb and Alpaslan, 2008) or Management Control Logic (Shipilov, Greve and Rowley, 2010). Agency Logic (Zajac and Westphal, 2004) is also known as Investor Capitalism (Green et al., 2008), Board Reform Logic (Shipilov et al., 2010), and Logic of Shareholder Value Maximisation (Lok, 2010). Stakeholder Logic - which is linked to stakeholder theory (Donaldson and Preston, 1995) - is also known as Value Logic (du Plessis, 2008). Note that Stakeholder Logic is comparable to Corporate Logic, except that the corporate objective is stakeholder value maximisation, not shareholder value maximisation (du Plessis, 2008). These three Logics are related to various organisational theories as aforementioned, but differ from theories in that these Logics represented shared beliefs that are not necessarily internally consistent, welldefined or unchanging. For instance, Agency Logic encompasses the notion of executives following narrow and enlightened self-interest (Lok, 2010; also see Rocha and Ghoshal, 2006), which is analogous of a short- versus long-term outlook on firm performance.

An institutional logics perspective can be viewed as a branch of institutional theory of which there are many (for reviews, see Schmidt, 2010; Scott, 2008). It could also be viewed as "a metatheoretical framework for analysing the interrelationships among institutions, individuals, and organizations in social systems" (Thornton et al., 2012, p.2). With respect to this paper, it relates to how sets of ideas with durable meanings - Logics and principles constrain and enable the remuneration committee's decision-making. This focus is an echo of John Maynard Keynes' concern that economic theories influence practice: he famously wrote, "Madmen [sic] in authority, who hear voices in the air, are distilling their frenzy from some academic scribbler of a few years back" (Keynes, 1936, p.383). Institutional theory and an 
institutional logic perspective provide a lens through which the influence of theory on practice can be studied. In particular, whether the remuneration committee believes it should use remuneration schemes to foster loyalty and goodwill from executives (Corporate and Stakeholder Logic) or to control the assumed opportunistic behaviour of executives (Agency Logic), in order to maximise shareholder value (Agency and Corporate Logic) or maximise stakeholder value (Stakeholder Logic).

Prior research has found that there are multiple, competing institutional logics of corporate governance that influence organisational decision-making, particularly between Corporate Logic and Agency Logic (e.g. Green et al., 2008). Heugens and Otten (2007) found that multiple Logics are embedded in the recommendations of corporate governance codes from around the globe, although there were differences between countries. In the USA, studies have documented a shift from Corporate Logic to Agency Logic (Jung, 2014; Rhee and Fiss, 2014; Zajac and Westphal, 2004), although this transition has been contested (Fiss, Kennedy and Davis, 2012; Green et al., 2008) and has given rise to practices that symbolically conform to Agency Logic (Joseph, Ocasio and McDonnell, 2014; Westphal and Graebner, 2010; Zajac and Westphal, 2004). More recently, there are signs that there has been a shift towards Corporate Logic (Westphal and Park, 2012) and Stakeholder Logic (Ioannou and Serafeim, 2015). Other countries have also experienced a shift towards Agency Logic including Canada (Shipilov et al., 2010), Germany (Chizema, 2008, 2010; Chizema and Buck, 2006; Fiss and Zajac, 2004, 2006; Sanders and Tushke, 2007), Japan (Desender, Aguilera, Lopezpuertas-Lamy and Cerspi, 2016; Morris, Hassard and McCann, 2008), Netherlands (Bezemer, Zajac, Naumovska, van den Bosch and Volberda, 2015) and the UK (Ezzamel, Willmott and Worthington, 2008; Lok, 2010), although these countries are still experiencing 
an institutional battle between Logics with evidence of symbolic practices (e.g. Fiss and Zajac, 2004, 2006).

There are two significant problems with these studies. Firstly, the majority of the aforementioned studies have treated boardroom decision-making as a black box with an emphasis on the diffusion of practices over time and the antecedents and effects of diffusion (e.g. Westphal and colleagues). A few studies (Ezzamel et al., 2008; Green et al., 2008; Lok, 2010) have examined how these Logics have shaped decision-making. Interestingly, Lok (2010) found that there may be a merging of Corporate Logic and Agency Logic. Secondly, none of these studies have investigated how remuneration committees make and report decisions. Instead, the focal point has been on symbolic practices. For example, US investors react positively to the adoption of long-term incentive plans, particularly if justified by the language of agency theory, irrespective of whether the plans are subsequently implemented (Westphal and Zajac, 1998, 2013; Zajac and Westphal, 1995). Overall, scholars have used an institutional logics perspective to examine socio-economic, not socio-psychological phenomena. Thus, this paper's point of difference is to bring an institutional logics perspective to bear on qualitative research on executive remuneration in order to unpack the black box that is the remuneration committee and its decision-making.

\section{Remuneration Principles}

Remuneration principles are abstract, affirmative statements that frame how remuneration decisions should be made. Distinct from rules, principles do not prohibit any remuneration practices and processes; principles are loose, not tight constraints because of they are open to interpretation. Drawing on the notion of induction, 14 remuneration principles have been derived from 45 qualitative studies on executive remuneration (for a summary, see Appendix 
A). Table 1 provides definitions and critique of the 14 remuneration principles, labelled: market, human resources, fairness, pay-for-performance, strategic pay, balanced measurement, out-performance, alignment, motivation, ability-to-pay, conformance, independence, consultant and transparency. This is an extensive, but not an exhaustive list; future research and debate among academics, practitioners, investors, regulators, etc. will be required to determine if any remuneration principles are missing or could be omitted and if the definitions are adequate. As highlighted in Table 1, the definitions are open to interpretation. For example, the pay-for-performance principle does not specify the optimality (or desired strength) of the relationship. Operationalising the remuneration principles will require remuneration committees to make many decisions that may vary across organisations, industries, countries, time periods, etc. (Malsch, Tremblay and Gendron, 2012; Pepper and Gore, 2014); these differences are not explored in this paper.

\section{----- Insert Table 1 here -----}

Table 2 shows the strength of agreement with the remuneration principles amongst the directors, executives, consultants, investors, etc. whose opinions have been presented in the 45 qualitative studies reviewed (for a detailed breakdown, see Appendix A). The subjects of those studies expressed views that were consistent with many of the principles, although some had views that were contrary. The principles with support in 10 or more studies are (from most to least support): pay-for-performance, market, consultant, motivation, conformance, human resources, strategic pay, and independence. Collectively, this means that executives will be motivated to exert the desired effort if their remuneration is contingent on (1) firm performance, (2) firm strategy, (3) remuneration of their peers and (4) their expectations, while independent directors, advised by remuneration consultants, decide how to make and 
report these decisions (e.g. Bender, 2004, Figure 1, p.531). On the other hand, principles that are disputed in four or more studies included (from most to least disagreement): motivation, consultant, market, conformance, transparency, and pay-for-performance. Some subjects (including executives) expressed doubt about the motivational effects of short- and long-term incentive schemes (e.g. Pennings, 1993; Bender, 2004; Pepper, Gore and Crossman, 2013), and the general belief of directors that their executives are above-average performers, deserving of above-average pay (e.g. Bender and Moir, 2006; Hermanson, Tompkins, Veliyath and Yer, 2012; Perkins and Hendry, 2005).

----- Insert Table 2 here -----

Given the strength of agreement and disagreement with the remuneration principles, it is most likely that both Agency Logic and Corporate Logic, but not Stakeholder Logic, are embedded in the business discourse on executive remuneration. While there is support for the conformance principle - which makes reference to the interests of stakeholders, rather than only shareholders - non-shareholding stakeholders such as customers, employees, suppliers, etc. are rarely mentioned in the 45 studies (cf. Bender and Moir, 2006). Support for the conformance principle relates to the desire of remuneration committees to avoid media and public scrutiny (Bender, 2011b; Hermanson et al., 2012; Malsch et al., 2012). The general consensus of the subjects in the 45 studies is that publicly listed companies exist to enhance shareholder value, but they disagreed on whether or not monetary incentives are necessary to ensure that executives will act in the best interests of shareholders (e.g. Pennings, 1993; Pepper et al., 2013; St-Onge, Magnan, Thorne and Raymond, 2001). Agency Logic's assumption that executives are opportunistic and extrinsically-motivated is reflected in the pay-for-performance, alignment and motivation principles, and its prescription for non- 
executive directors to monitor executives is reflected in the independence principle. In contrast, Corporate Logic's assumption that executives are intrinsically-motivated and desire to be paid equitably given their professional work ethic is reflected in the market, human resources and fairness principles as well as in the disagreement with the pay-for-performance, alignment and motivation principles.

Consistent with other studies, Hermanson et al. (2012, p.667) found, "Many of the interviewees appeared to describe a pervasive tension between resource dependence theory (paying enough to be reasonable in the market and retain executives through fair compensation) and agency theory (pay for performance, proper alignment of incentives, and shareholder-friendly compensation)." This tension underscores that Agency Logic and Corporate Logic are competing, not co-existing in business discourse. The distribution of belief in Agency Logic and/or Corporate Logic amongst directors, executives, consultants, investors, etc. is unknown at present, but is unlikely to be one-sided. Remuneration committees and powerful stakeholders (e.g. investors) may favour Agency Logic, Corporate Logic, both Agency Logic and Corporate Logic, or alternative Logics. This gives scope to remuneration committees to use empty rhetoric and symbolic practices to resolve tension inside and outside the boardroom. For example, there has been both an increase in the proportion of at-risk remuneration and total remuneration for CEOs of large publicly listed companies in recent decades (Fernandes, Ferreira, Matos and Murphy, 2013; Frydman and Saks, 2010), but the increase in the proportion of at-risk remuneration may be symbolic conformance with Agency Logic as remuneration committees may have also increased the total potential remuneration, ensuring that CEOs are paid comparably to their peers consistent with Corporate Logic - irrespective of firm performance. This line of reasoning is 
consistent with Bender's (2007) finding that CEO pay almost always increases following changes to remuneration practices.

While the Logics and remuneration principles provide remuneration committees with a framework for making and reporting decisions, how the Logics and principles affect those decisions is indeterminate at present. This is because prior studies have focused on executive remuneration in general terms, not specific decisions that remuneration committees have made. The rare exceptions are Bender's (2007) study of why 12 remuneration committees made specific changes to their remuneration schemes and Ogden and Watson's (2008) study of the choice of the peer group and performance measures for the long-term incentive plan in five companies. In making and reporting decisions, the remuneration committee will have to prioritise the remuneration principles in some manner because not all principles can be simultaneously enacted. Future research should examine how multiple Logics - the varying beliefs of directors, executives, etc. - affect the prioritisation and symbolic use of the principles. Qualitative research methods and experiments can be employed to unpack how remuneration committees make and report specific decisions. Further, quantitative research methods can be employed to survey the distribution of belief among directors, executives, investors, etc. in a similar vein to Pepper and Gore (2014) and to survey the incidence of remuneration principles in codes and corporate annual reports, extending the work of Zajac and Westphal (1995), Wade et al. (1997) and Point and Tyson (2006).

\section{Remuneration Practices}

Table 3 presents a range of remuneration practices, how remuneration principles influence those practices, and other relevant findings from prior qualitative research. The typical remuneration package for executives includes base salary and benefits, pension (or 
superannuation), other payments for recruitment, retention and severance, short-term incentives and long-term incentives (Chambers and Weight, 2008; Fernandes et al., 2013; Murphy, 1999, 2013). The remuneration package for executives differs across industries, countries and time periods (Fernandes et al., 2013; Frydman and Saks, 2010; Sanchez-Marin, 2008). However, the 45 studies reviewed here have not extensively investigated many of the remuneration practices listed in Table 3. Prior qualitative research has examined multiple aspects of long-term incentives in depth (e.g. Ogden and Watson, 2008), but typically only discuss executive remuneration in general terms (e.g. Bender, 2004; Hermanson et al., 2012; Pennings, 1993). Nevertheless, Table 3 shows that the remuneration principles shape how remuneration decisions are made and reported. The market, human resources, consultant and conformance principles affect the remuneration practices that are selected and the level of remuneration. The pay-for-performance, strategic pay, alignment and motivation principles affect the selection of performance measures and the mix of fixed and variable pay. Notably the potential value of short- and long-term incentives is often expressed as a multiple of base salary. This means that the selection of the level relative to a peer group (e.g. lower quartile, medium or upper quartile) - an operationalization of the market and human resources principles - is the most critical decision on which executive remuneration rests (e.g. Hermanson et al., 2012; Kostiander and Ikaheimo, 2012; Ogden and Watson, 2012).

----- Insert Table 3 here -----

In contrast to Corporate Logic, there is a negative connation of executives in both academic and media discourse; instead of being portrayed as trustworthy professionals, an image of greedy opportunists has emerged (e.g. the Institute of Policy Studies has published an annual review of "executive excess" in the USA since 1994). This image has been strengthened by 
traditional research, which found a weak relationship between CEO pay and firm performance as well as companies widely adopting symbolic remuneration practices. However, consistent with Corporate Logic, directors and executives do not see themselves as greedy opportunists, and this is why the market and human resources principles strongly influence how and how much executives are paid (e.g. Main, 1993; Malsch et al., 2012; St-Onge et al., 2001). Another significant tenet of Corporate Logic is that the underlying belief that all executives are above-average performers, deserving of above-average remuneration (e.g. Hermanson et al., 2012; Malsch et al., 2012; Ogden and Watson, 2012); this should, in theory, be countered by the ability-to-pay and fairness principles, but these principles have limited support (see Table 2). The implication is that Corporate Logic is weak or less than fully institutionalised. This may be due to boards of directors being comprised of former executives, who are perhaps too sympathetic towards current executives (Ogden and Watson, 2012), and/or the institutionalisation of Agency Logic with its emphasis on incentive schemes.

Agency Logic has popular appeal, casting executives as the villain, investors as the victim and non-executive directors as the hero. Through the use of a complex myriad of incentive schemes, the remuneration committee (comprised of non-executive directors) will bring the executives to justice, or at least not pay them more than their contribution to firm performance (e.g. Bender and Moir, 2006; Hermanson et al., 2012; Malsch et al., 2012). This narrative is borne out in strong support for the pay-for-performance, strategic pay, alignment, motivation, independence and transparency principles (see Table 2). The typical remuneration package for executives is substantively shaped by these principles. Both short- and long-term incentives are dependent on multiple performance measures with relative targets. As a compensation committee member contemplated, "This business [i.e., CEO compensation] is one of the most measured businesses on a quantitative basis around..." (Malsch, et al., 2012, 
p.408). However, this level of complexity is not rational because the computational capabilities of executives are bounded and they cannot possibly choose the course of action that maximises their remuneration (Main, Jackson, Pymm and Wright, 2008; Pepper et al., 2013). Thus, the institutionalisation of Agency Logic has resulted in a kind of madness, where increasingly complex incentive schemes are touted as the cure to corporate failures and perceived executive greed (Murphy, 2013; Murphy and Jensen, 2011), despite the reality that executives heavily discount the value of complex and long-term incentive schemes (Pepper et al., 2013; Pepper and Gore, 2014).

Together, Agency Logic and Corporate Logic provide remuneration committees with a set of beliefs and notions that are contradictory and somewhat irrational from both organisational and societal perspectives. As shown in Table 3, all of the remuneration practices can be justified with multiple remuneration principles, despite Agency Logic and Corporate Logic having opposing assumptions and prescriptions. For example, St-Onge et al. (2001) found stock option plans can be used to attract and retain executives (human resources principle), ensure executives are paid competitively (market principle), motivate executives to exert effort (motivation principle) and align executives' interests with those of shareholders (alignment principle). There are, of course, tensions between these principles, and these have been noted by many scholars (e.g. Bender and Moir, 2006; Hermanson et al., 2012; Main et al., 2008, 2011). For example, Main et al. (2008, p.235) concluded, “...efforts by remuneration committees to conform may lead them away from implementing remuneration arrangements that are in the best interest of long term shareholder value", which casts doubt on the compatibility of the conformance and alignment principles. However, as both Agency Logic and Corporate Logic appear to be legitimate discourses among powerful stakeholders such as investors, media, regulators, etc. (e.g. Lok, 2010; Westphal and Park, 2012), the 
incompatibility of these Logics affords remuneration committees much discretion in designing remuneration packages for executives.

Further research is required to fully explore how the remuneration principles both individually and as a set affect the design of remuneration packages for executives in the vein of Bender (2007), Ogden and Watson (2008) and St-Onge et al. (2001). Scholars can use qualitative research methods to explore how and why remuneration committees choose specific remuneration practices. It may be that the institutionalisation of both Agency Logic and Corporate Logic has crowded out alternative remuneration principles and practices, thereby constraining remuneration committees. Drawing on the notion of institutional identity (Lok, 2010), non-executive directors may feel that members of remuneration committees are supposed to speak the language of and adopt the practices of Agency Logic and Corporate Logic, irrespective of whether they believe in the efficacy of the associated remuneration principles and practices. Also, scholars can use quantitative research methods (e.g. cluster analysis) to determine the extent to which the remuneration practices of firms are consistent each of the Logics. The findings from qualitative research can be drawn on to aid scholars as they formulate and test hypotheses, so that they are able to continue to unpack the decision making of remuneration committees (e.g. Pepper et al., 2013 employed qualitative and quantitative methods).

Experiments are another avenue for future research. There is only one experimental study in this paper's sample of qualitative research: Wilkins, Hermanson and Cohen (2015). In that study, the authors examined the conditions under which remuneration committees are likely to decrease a CEO's bonus target partway through the performance period. There are a myriad of remuneration decisions that the remuneration committee faces and these could be 
studied using a similar approach. Particular attention could be given to how directors' beliefs - represented by the Logics and principles - influence their decision-making. Some interesting experimental manipulations may be related to the CEO's behaviour (self-interested versus altruistic), the quantum of CEO pay and societal expectations (one Logic being dominant or multiple, competing Logics). With respect to the latter, it may be that the remuneration committee perceives greater latitude in decision-making when there are multiple Logics rather than when one Logic is dominant. Also, the remuneration committee may use symbolic remuneration practices when there is a mismatch between its preferred Logic and society's (or shareholders') preferred Logic (Zajac and Westphal, 2004).

\section{Remuneration Processes}

Figure 1 depicts that relational, historical, competitive and institutional pressures influence how the remuneration committee makes and reports decisions (Crombie, 2013). Relational pressures arise from the remuneration committee's interaction with the board of directors, CEO (and other executives), directors within their network, professionals (e.g. auditors and lawyers) and consultants, regulators, media, financial analysts, investors, bankers, etc. (see discursive institutionalism, Schmidt, 2010). Historical pressures arise from the collective, past experiences of the members of the remuneration committee. Those experiences can be educational, personal or professional. Historical pressures are particularly influential because people tend to make decisions that are consistent with past decisions, in order to reduce uncertainty (see historical institutionalism, Schmidt, 2010). Competitive pressure arises from the markets in which an organisation participates such as those for labour, capital and products/services (see rational choice institutionalism, Schmidt, 2010). Institutional pressures - coercive/regulative, normative and mimetic - arise from the shared beliefs, norms and values that permeate a sector of society (or an organisational field) (see sociological 
institutionalism, Schmidt, 2010). It is through these pressures that Logics will be diffused and institutionalised, depending upon the strength and homogeneity of the pressures, diversity of beliefs among influential parties, degree of institutional entrepreneurship and resilience of existing institutions to external jolts (Scott, 2008; Thornton et al., 2012).

----- Insert Figure 1 here -----

Corporate Logic implies that the remuneration committee should have a strategic role, which necessitates a close working relationship with the CEO; whereas Agency Logic implies that they should have an evaluator/judging role, meaning they should operate independently of the CEO. Consistent with Corporate Logic, prior qualitative research has found that there is a complex relationship between the remuneration committee and $\mathrm{CEO}$, where the CEO certainly does influence the remuneration committee, but this influence is not undue (Bender 2004, 2011b; Hermanson et al., 2012; Main, 1993; Main et al., 2008, 2011; Perkins and Hendry, 2005; Ogden and Watson, 2004, 2012). The primary concern of remuneration committees is attracting and retaining talented executives, not policing opportunistic executives (Conyon et al., 2000; Hermanson et al., 2012; Malsch et al., 2012; Ogden and Watson, 2012). This does not mean that remuneration committees are not wary of being unduly influenced and they do indeed assert that much effort goes into negotiating the CEO's contract and any changes to it, evaluating the CEO's performance and ratifying the CEO's remuneration decisions regarding his/her direct reports (Hermanson et al., 2012; Main et al., 2008, 2011; Perkins and Hendry, 2005). However, remuneration committees are susceptible to groupthink and adopting remuneration practices that are common amongst their peers (i.e. historical and mimetic pressures). 
Remuneration committees are also compelled to adhere to best practice (i.e. coercive and normative pressures), reflected in their strong support for the consultant and conformance principles (see Table 2). The reliance on remuneration consultants for data and advice is a common theme in the studies reviewed, although their influence is downplayed by nonexecutive directors (Bender 2011a; Hermanson et al., 2012; Main, 1993; Ogden and Watson, 2012). It has been very rare to find remuneration committees that do not employ remuneration consultants with one case in Main (1993) and another in Bender (2011a); remuneration committees see them as necessary evil (Perkins and Hendry, 2005). Remuneration consultants provide a foundation on which remuneration committees build their remuneration practices; thus, they diffuse and legitimise certain beliefs, norms, values, etc. (Bender, 2011a; Malsch et al., 2012). This partially explains why the market and human resources principles are so strongly supported. Similarly, code issuers (e.g. regulators, stock exchanges, etc.) influence remuneration committees, diffusing best practice (Bender, 2007; Kovacevic, 2009; Main, 1993; Main et al., 2008). However, Ogden and Watson (2008) found that this coercive pressure is not necessarily strong; remuneration committees observed the UK code to be non-specific with respect to the design of long-term incentive plans.

Shareholders and non-shareholding stakeholders exert considerable influence over remuneration committees in both direct and perceived terms (Bender and Moir, 2006; Hermanson et al., 2012; Kovacevic, 2009). Shareholders (e.g. institutional investors), media and regulators exert a direct influence; the board - which includes members of the remuneration committee - will meet shareholders and respond to information requests from media and regulators (Bender and Moir, 2006; Hermanson et al., 2012; Kovacevic, 2009; Main et al., 2011). However, the influence of non-shareholding stakeholders tends to be less direct and more perceived. Remuneration committees are very concerned about how the 
media and public will react to their decisions; thus, it is their perception of how nonshareholding stakeholders will react that matters (Bender and Moir, 2006; Hermanson et al., 2012; Malsch et al., 2012). This is inconsistent with Stakeholder Logic as remuneration committees are not aiming to direct executives to act in the best interests of all stakeholders, but wanting to avoid negative attention. Instead, remuneration committees work with executives to ensure that the remuneration policies and practices will encourage, but not necessarily coerce executives and employees to act in the best interests of shareholders (Bender and Moir, 2006; Hermanson et al., 2012; Ogden and Watson, 2006). This is more consistent with Corporate Logic than Agency Logic.

While there is no doubt that relational, historical, competitive and institutional pressures influence remuneration committees, the nature and strength of that influence is less well understood at present. However, the diffusion of Agency Logic and Corporate Logic has not been studied at the micro- or organisational-level with respect to executive remuneration; thus, it is difficult to pinpoint how these Logics have become institutionalised. The main deficiency in the studies reviewed is that almost all of them have investigated executive remuneration in a general sense, rather than focusing on specific decisions that remuneration committees have made. A rare exception is Ogden and Watson (2008), whose findings discounted the strength of normative pressure on five case companies. Future qualitative research should focus on a small sample of companies in order to investigate the relative strengths of the pressures described here. For example, remuneration consultants are influential, but remuneration committees are somewhat dismissive of their influence (Bender, 2011a; Perkins and Hendry, 2005); a close examination of how decisions are made should reveal the extent of their influence. Further, unlike quantitative research that has focused on symbolic practices, qualitative research has rarely investigated the extent to which 
remuneration committees decouple internal decisions from external reporting in order to mitigate the various pressures. Finally, experiments could be carried out to understand how the remuneration committee is likely to make and report decisions when competitive and institutional pressures vary in strength.

\section{Conclusion}

The central thesis of an institutional logics perspective is that ideas matter; beliefs, norms, rules, values, etc. that are embedded in society's (or a sector of society's) collective consciousness have the power to shape people's behaviour (Thornton et al., 2012). This paper shows that three ideas - Agency Logic, Corporate Logic and, to a much lesser extent, Stakeholder Logic - are embedded in the remuneration principles, practices and processes of publicly listed companies. Remuneration committees draw on a range of remuneration principles - in which the Logics are reflected - to design remuneration packages for executives and to evaluate their performance, so that executives act in the best interests of shareholders. This instrumental approach is tempered; not all non-executive directors believe that monetary incentives motivate executives and instead, they aim to pay executives comparably to their peers. These remuneration principles and practices are most likely diffused through professional networks (e.g. remuneration consultants). The principles legitimate the decisions of remuneration committees and defend them against criticism from shareholders, regulators and the media. However, given the general nature of the qualitative studies reviewed, the extent to which each of the Logics has become substantively or symbolically embedded in the remuneration decisions is not yet fully understood; there is much scope for future qualitative, archival and experimental research in this area as have been noted throughout this paper. 
There has been much criticism of executives, particularly how much money they are paid, and the remuneration committees that assess their performance and award their pay. Such criticism is desirable in a democratic, capitalist society; corporations should be held to account. The response of remuneration committees to such criticism has been to draw on a range of remuneration principles to defend and legitimise their decisions, and to design increasingly complex remuneration packages for executives. It is difficult to argue with an approach that advocates competitive remuneration, linked to firm performance. However, it is impossible for executives to rationally respond to the myriad of performance measures and incentives schemes which they are subject; undoubtedly, executives ignore some (e.g. longterm incentives) and focus their efforts on others. Further, the belief that remuneration committees only hire executives that are above-average performers, deserving of aboveaverage pay - resulting in an overemphasis of the market and human resources principles - is a logical impossibility. Echoing Hodak's (2005) sentiment, remuneration committees are advised to be more sceptical of the remuneration principles and to simplify their remuneration practices. If money is not a strong motivator for some executives, perhaps they will not object to being paid below the median. Shareholders, regulators, the media, etc. are also advised to demand simpler remuneration packages for executives, and to be wary of remuneration policies and practices that are illogical or lack substance.

\section{References}

Adams, R. B and Gianneti, M. (2012) 'Is pay a matter of values?', International Review of Finance, Vol.12 No.2, pp.133-173.

Adamson, M., Manson, S. and Zakaria, I. (2014) 'Executive remuneration consultancy in the UK: Exploring a professional project through the lens of institutional work', Journal of Professions and Organization, Vol.2, No.1, pp.19-37.

ASX Corporate Governance Council (2014) Corporate Governance Principles and Recommendations, $3^{\text {rd }}$ ed., ASX Corporate Governance Council, Sydney.

Aureli, S. and Salvatori, F. (2012) 'An investigation on possible links between risk management, performance measurement and reward schemes', Accounting and Management Information Systems, Vol.11 No.3, pp.306-334. 
Bart, C., Chan, Y. L. and Kanagaretnam, K. (2011) 'What questions do board members in public service organizations ask about executive compensation?' Accounting Perspectives, Vol.10 No.2, pp.83-108.

Bebchuk, L. A. and Fried, J. (2004) Pay without performance: The unfulfilled promise of executive compensation, Harvard University Press, Cambridge, MA.

Beer, M. and Katz, N. (2003) 'Do incentives work? The perceptions of a worldwide sample of senior executives', Human Resource Planning, Vol.26 No.3, pp.30-44.

Bender, R. (2003) 'How executive directors' remuneration is determined in two FTSE 350 utilities', Corporate Governance: An International Review, Vol.11 No.3, pp.206-217.

Bender, R. (2004) 'Why do companies use performance-related pay for their executive directors?', Corporate Governance: An International Review, Vol.12 No.4, pp.521533.

Bender, R. (2007) 'Onwards and upwards: Why companies change their executive remuneration schemes, and why this leads to increases in pay', Corporate Governance: An International Review, Vol15. No.5, pp.709-723.

Bender, R. (2011a) 'Paying for advice: The role of the remuneration consultant in U.K. listed companies', Vanderberbilt Law Review, Vol.64 No.2, pp.361-396.

Bender, R. (2011b) The Platonic Remuneration Committee. http://ssrn.com/abstract=1782642 (Accessed 26 February 2014).

Bender, R. and Moir, L. (2006) 'Does 'Best practice' in setting executive pay in the UK encourage 'Good' behaviour?', Journal of Business Ethics, Vol.67 No.1, pp.75-91.

Bezemer, P-J., Zajac, E. J., Naumovska, I., van den Bosch, F. A. J. and Volberda, H. W. (2015) 'Power and paradigms: The Dutch response to pressures for shareholder value', Corporate Governance: An International Review, Vol.23, No.1, pp.60-75.

Business Roundtable (2012) Principles of Corporate Governance, Business Roundtable, Washington, DC.

Chambers, A.D. and Weight, C. (2008) Corporate Governance Handbook, Tottel Publishing, Haywards Heath.

Chandler Jr., A.D. (1962) Strategy and structure: Chapters in the history of the American industrial enterprise, MIT Press, Cambridge.

Chapman, J. and Kelliher, C. (2011) 'Influences on reward mix determination: Reward consultants' perspectives', Employee Relations, Vol.33 No.2, pp.121-139.

Chizema, A. (2008) 'Institutions and voluntary compliance: The disclosure of individual executive pay in Germany', Corporate Governance: An International Review, Vol.16 No.4, pp.359-374.

Chizema, A. (2010) 'Early and late adoption of American-style executive pay in Germany: Governance and institutions', Journal of World Business, Vol.45 No.1, pp.9-18.

Chizema, A. and Buck, T. (2006) 'Neo-institutional theory and institutional change: Towards empirical tests on the "Americanization" of German executive pay', International Business Review, Vol.15 No.5, pp.488-504.

Clarke, R. N., Conyon, M. J. and Peck, S. I. (1998) 'Corporate governance and directors' remuneration: Views from the top', Business Strategy Review, Vol.9 No.4, pp.21-30.

Conyon, M. J., Peck, S. I., Read, L. E. and Sadler, G. V. (2000) 'The structure of executive compensation contracts: UK evidence', Long Range Planning, Vol.33, pp.478-503.

Cremers, K. J. M. and Grinstein, Y. (2014) 'Does the market for CEO talent explain controversial CEO pay practices?', Review of Finance, Vol.18, pp.921-960.

Crombie, N. A. (2013) Institutional logics of corporate governance and the discourse on executive remuneration, doctoral dissertation, University of Canterbury, Christchurch, New Zealand, http://hdl.handle.net/10092/8202 (Accessed 3 May, 2014). 
Dalton, D. R., Daily, C. M., Certo, S. T. and Roengpitya, R. (2003) 'Meta-analyses of financial performance and equity: Fusion or confusion?', Academy of Management Journal, Vol.46 No.1, pp.13-26.

Dalton, D. R., Hitt, M. A., Certo, S. T. and Dalton, M. (2007) 'The fundamental agency problem and its mitigation: Independence, equity, and the market for corporate control', Academy of Management Annals, Vol.1 No.1, pp.1-64.

Davis, J. H., Schoorman, F. D. and Donaldson, L. (1997) 'Toward a stewardship theory of management', Academy of Management Review, Vol.22, pp.20-47.

Desender, K. A., Aguilera, R. V., Lopezpuertas-Lamy, M. and Crespi, R. (2016) 'A clash of governance logics: Foreign ownership and board monitoring', Strategic Management Journal, Vol.37, No.2, pp.349-369.

Dobbin, F. and Jung, J. (2010) 'The misapplication of Mr. Michael Jensen: How agency theory brought down the economy and why it might again', Research in the Sociology of Organizations, Vol.30B, pp.29-64.

Donaldson, T. and Preston, L. E. (1995) 'The stakeholder theory of the corporation: Concepts, evidence, and implications', Academy of Management Review, Vol.20, pp.65-91.

du Plessis, C. J. A. (2008) 'Ethical failure under the agency logic: Grounding governance reform in a logic of value', Group and Organization Management, Vol.33, pp.781804.

Ezzamel, M., Willmott, H. and Worthington, F. (2008) 'Manufacturing shareholder value: The role of accounting in organizational transformation', Accounting, Organizations and Society, Vol.33, pp. 107-140.

Faulconbridge, J. R., Beaverstock, J. V., Hall, S. and Hewitson, A. (2009) 'The 'war for talent': The gatekeeper role of executive search firms in elite labour markets', Geoforum, Vol.40, pp.800-808.

Fernandes, N., Ferreira, M. A., Matos, P. and Murphy, K. J. (2013) 'Are U.S. CEOs paid more? New international evidence', The Review of Financial Studies, Vol.26 No.2, pp.323-367.

Ferraro, F., Pfeffer, J. and Sutton, R. I. (2005) 'Economics language and assumptions: How theories can become self-fulfilling', Academy of Management Review, Vol.30 No.1, pp.8-24.

Financial Reporting Council (2014) The UK Corporate Governance Code, Financial Reporting Council, London.

Fiss, P. C., Kennedy, M. T. and Davis, G. F. (2012) 'How golden parachutes unfolded: Diffusion and variation of a controversial practice', Organization Science, Vol.23 No.4, pp.1077-1099.

Fiss, P. C. and Zajac, E. J. (2004) 'The diffusion of ideas over contested terrain: The (non) adoption of a shareholder value orientation among German firms', Administrative Science Quarterly, Vol.49 No.4, pp.501-534.

Fiss, P. C. and Zajac, E. J. (2006) 'The symbolic management of strategic change: Sensegiving via framing and decoupling', Academy of Management Journal, Vol.49 No.6, pp.1173-1193.

Franco-Santos, M., Bourne, R. and Huntington, R. (2004) 'Executive pay and performance measurement practices in the UK', Measuring Business Excellence, Vol.8 No.3, pp.511.

Frydman, C. and Saks, R. E. (2010) 'Executive compensation: A new view from a long-term perspective, 1936-2005', Review of Financial Studies, Vol.23 No.5, pp.2099-2138.

Gerhart, B. and Fang, M. (2014) 'Pay for (individual) performance: Issues, claims, evidence and the role of sorting effects', Human Resource Management Review, Vol.24, pp.4152 . 
Gerhart, B., Rynes S. L. and Fulmer, I. S. (2009) 'Pay and performance: Individuals, groups, and executives', Academy of Management Annals, Vol.3 No.1, pp.251-315.

Ghoshal, S. (2005) 'Bad management theories are destroying good management practices', Academy of Management Learning \& Education, Vol.4 No.1, pp.75-91.

Gomez-Mejia, L. R., Berrone, P. and Franco-Santos, M. (2010) Compensation and organizational performance: theory, research, and practice, M. E. Sharpe, New York.

Graham, J. R., Harvey C. R. and Puri, M. (2013) 'Managerial attitudes and corporate actions', Journal of Financial Economics, Vol.109, pp.103-121.

Green Jr., S. E., Babb, M. and Alpaslan, C. M. (2008) 'Institutional field dynamics and the competition between institutional logics: The role of rhetoric in the evolving control of the modern corporation', Management Communication Quarterly, Vol.22 No.1, pp.40-73.

Haynes, K. T., Campbell, J. T. and Hitt, M. A. (2014) 'When more is not enough: Executive greed and its influence on shareholder wealth', Journal of Management, forthcoming, pp.1-30.

Hermanson, D. R., Tompkins, J. G., Veliyath, R. and Yer, Z. (2012) 'The compensation committee process', Contemporary Accounting Research, Vol.29 No.3, pp.666-709.

Heugens, P. M. A. R. and Otten, J. A. (2007) 'Beyond the dichotomous worlds hypothesis: towards a plurality of corporate governance logics', Corporate Governance: An International Review, Vol.15 No.6, pp.1288-1300.

Hodak, M. (2005) 'Letting go of norm: How executive compensation can do better than "best practices", Journal of Applied Corporate Finance, Vol.17 No.4, pp.115-124.

Ioannou, I. and Serafeim, G. (2015) 'The impact of corporate social responsibility on investment recommendations: Analysts' perceptions and shifting institutional logics', Strategic Management Journal, Vol.36, No.7, pp.1053-1081.

Jensen, M. C. and Meckling, W. H. (1976) 'Theory of the firm: Managerial behavior, agency costs and ownership structure', Journal of Financial Economics, Vol.3, pp.305-360.

Jensen, M. C. and Murphy, K. J. (1990) 'Performance pay and top-management incentives', The Journal of Political Economy, Vol.98 No.2, pp.225-264.

Johl, S. K., Bruce, A. and Binks, M. (2013) 'Remuneration structure and corporate entrepreneurship: A UK study', International Journal of Business and Management, Vol. 8, No. 7, pp.116-126.

Joseph, J., Ocasio, W. and McDonnell, M. (2014) 'The structural elaboration of board independence: Executive power, institutional logics, and the adoption of CEO-only board structures in U.S. corporate governance', Academy of Management Journal, Vol.57, No.6, pp.1834-1858.

Jung, J. (2014) 'Political contestation at the top: Politics of outsider succession at U.S. corporations', Organization Studies, Vol.35, No.5, pp.727-764.

Kaen, F. R., Kaufman, A. and Zacharias, L. (1988) 'American political values and agency theory: A perspective', Journal of Business Ethics, Vol.7 No.11, pp.805-820.

Keynes, J. M. (1936) The General Theory of Interest, Employment and Money, Macmillan, London.

Kostiander, L. and Ikaheimo, S. (2012) “"Independent” consultants' role in the executive remuneration design process under restrictive guidelines', Corporate Governance: An International Review, Vol.20 No.1, pp.64-83.

Kovacevic, S. (2009). 'Disclosed: An exploration of board remuneration committee challenges', Asia Pacific Journal of Human Resources, Vol.47 No.2, pp.201-218.

Lan, L. L. and Heracleous, L. (2010) 'Rethinking agency theory: The view from law', Academy of Management Review, Vol.35, pp.294-314. 
Lawler, E. E. and Finegold, D. (2007) CEO compensation: What board members think, Centre for Effective Organizations Publication G 07-8 (518). http://ceo.usc.edu/pdf/G078518.pdf (Accessed 5 January 2012).

Lok, J. (2010) 'Institutional logics as identity projects', Academy of Management Journal, Vol.53 No.6, pp.1305-1335.

Lubatkin, M., Lane, P. J., Collin, S. and Very, P. (2007) 'An embeddedness framing of governance and opportunism: Towards a cross-nationally accommodating theory of agency', Journal of Organizational Behavior, Vol.28 No.1, pp.43-58.

Mace, M. L. (1971) Directors: Myth and Reality, Harvard University Graduate School of Business Administration, Boston, MA.

Main, B. G. M. (1993) 'Pay in the boardroom: Practice and procedures', Personnel Review, Vol.22 No.7, pp.3-14.

Main, B. G. M., Belfield, R. and Turner, K. (2011) Is there a Negotiation Process in UK Remuneration Committees? Research Paper. http://homepages.ed.ac.uk/mainbg/Files/Is\%20there\%20a\%20Negotiation\%20Process \%20in\%20UK\%20Remuneration\%20Committees\%20-\%2011-11-2011.pdf (Accessed 21 December 2011).

Main, B. G. M., Jackson, C., Pymm, J. and Wright, V. (2008) 'The remuneration committee and strategic human resource management', Corporate Governance: An International Review, Vol.16 No.3, pp.225-238.

Malsch, B., Tremblay, M.-S. and Gendron, Y. (2012) 'Sense-making in compensation committees: A cultural theory perspective', Organization Studies, Vol.33 No.3, pp.38421 .

Morris, J., Hassard, J. and McCann, L. (2008) 'The resilience of 'institutionalized capitalism': Managing managers under 'shareholder capitalism' and 'managerial capitalism', Human Relations, Vol.61, pp.687-710.

Morris, T. J. and Fenton-O'Creevy, M. (1996) 'Opening up the black box: a UK case study of top managers' attitudes to their performance related pay', The International Journal of Human Resource Management, Vol.7 No.3, pp.708-720.

Murphy, K. J. (1999) 'Executive compensation', In Ashenfelter, O. and Card, D. (Eds.), Handbook of Labor Economics (Vol.3, pp.2485-2583), Elsevier Science Publishing, Amsterdam.

Murphy, K. J. (2013) 'Chapter 4: Executive compensation: Where we are, and how we got there', In Constantinides, G. M., Harris, M. and Stulz, R. M. (Eds.), Handbook of the Economics of Finance (Vol.2, pp.211-356), Elsevier Science Publishing, Amsterdam.

Murphy, K. J. and Jensen, M. C. (2011) CEO bonus plans: And how to fix them. Harvard Business School NOM Unit Working Paper 12-022. http://ssrn.com/abstract=1935654 (Accessed 11 January 2012).

O'Neill, G. (2007) 'A priori conceptions, methodological dogmatism and theory versus practice: Three reasons why CEO pay research lacks convergence', Corporate Governance: An International Review, Vol.15 No.4, pp.692-700.

Ogden, S., and Watson, R. (2004) 'Remuneration committees and CEO pay in the UK privatized water industry', Socio-Economic Review, Vol.2 No.1, pp.33-63.

Ogden, S. and Watson, R. (2008) 'Executive pay and the search for legitimacy: An investigation into how UK remuneration committees use corporate performance comparisons in long-term incentive pay decisions', Human Relations, Vol.61 No.5, pp.711-739.

Ogden, S. and Watson, R. (2012) 'Remuneration committees, pay consultants and the determination of executive directors' pay', British Journal of Management, Vol.23, pp.502-17. 
Otten, J. (2007) Theories on executive pay: A literature overview and critical assessment. Working Paper. http://ssrn.com/abstract=1088272 (Accessed 22 January 2009).

Pennings, J. M. (1993) 'Executive reward systems: A cross-national comparison', Journal of Management Studies, Vol.30 No.2, pp.261-280.

Pepper, A. and Gore, J. (2014) 'The economic psychology of incentives: An international study of top managers', Journal of World Business, Vol.49 No.3, pp.350-361.

Pepper, A. and Gore, J. (2015) 'Behavioral agency theory new foundations for theorizing about executive compensation', Journal of Management, Vol.41, No.4, pp.1045-1068.

Pepper, A., Gore, J. and Crossman, A. (2013) 'Are long-term incentive plans an effective and efficient way of motivating senior executives?', Human Resource Management, Vol.23 No.1, pp.36-51.

Perkins, S. J. and Hendry, C. (2005) 'Ordering top pay: Interpreting the signals', Journal of Management Studies, Vol.42 No.7, pp.1443-1468.

Pfeffer, J. and Salancik G. R. (1978) The External Control of Organizations: A Resource Dependence Perspective, Harper and Row, New York.

Pirson, M. A. and Lawrence, P. R. (2010) 'Humanism in business-towards a paradigm shift?', Journal of Business Ethics, Vol.93 No.4, pp.553-565.

Point, S. and Tyson, S. (2006) 'Top pay transparency in Europe: codes, convergence and clichés', International Journal of Human Resource Management, Vol.17 No.5, pp.812-830.

Rhee, E. and Fiss, P. (2014) 'Framing controversial actions: Regulatory focus, source credibility, and stock market reaction to poison pill adoption', Academy of Management Journal, Vol.57, No.6, pp.1734-1758.

Reilly, M. and Scott, D. (2005) 'An inside look at compensation committees', World At Work Journal, Vol.14 No.2, pp.34-40.

Rocha, H. O. and Ghoshal, S. (2006) 'Beyond self-interest revisited', Journal of Management Studies, Vol.43, pp.585-619.

Rost, K. and Osterloh, M. (2009) 'Management fashion pay-for-performance for CEOs', Schmalenbach Business Review, Vol.61, pp.119-149.

Sanchez-Marin, G. (2008) 'Chapter 2: National differences in compensation: the influence of the institutional and cultural context', in Gomez-Mejia, L. R. and S. Werner (Eds.), Global Compensation: Foundations and Perspectives (pp. 18-28). New York: Routledge.

Sanders, G. and Tuschke, A. (2007) 'The adoption of institutionally contested organizational practices: The emergence of stock option pay in Germany', Academy of Management Journal, Vol.50 No.1, pp.33-56.

Schmidt, V. A. (2010) 'Taking ideas and discourse seriously: explaining change through discursive institutionalism as the fourth 'new institutionalism', European Political Science Review, Vol.2 No.1, pp.1-25.

Scott, W. R. (2008). Institutions and Organizations: Ideas and Interests, $3^{\text {rd }}$ ed., Sage, Thousand Oaks.

Shipilov, A. V., Greve, H. R. and Rowley, T. J. (2010) 'When do interlocks matter? Institutional logics and the diffusion of multiple corporate governance practices', Academy of Management Journal, Vol.53 No.4, pp.845-864.

Spector, B. and Spittal, F. C. (2011) 'The ideology of executive bonuses: A historical perspective', Journal of Management History, Vol.17 No.3, pp.315-331.

Spira, L. F. and Bender, R. (2004) 'Compare and contrast: Perspectives on board committees', Corporate Governance: An International Review, Vol.12 No.4, pp.489499. 
St-Onge, S., Magnan, M., Thorne, L. and Raymond, S. (2001) 'The effectiveness of stock option plans: A field investigation of senior executives', Journal of Management Inquiry, Vol.10 No.3, pp.250-266.

Thornton, P. H., Ocasio, W. and Lounsbury, M. (2012) The Institutional Logics Perspective: A New Approach to Culture, Structure, and Process, Oxford University Press, Oxford.

Tosi Jr., H. L. and Gomez-Mejia, L. R. (1989) 'The decoupling of CEO pay and performance: An agency theory perspective', Administrative Science Quarterly, Vol.34 No.2, pp.169-189.

Tosi Jr., H. L. and Gomez-Mejia, L. R. (1994) 'CEO compensation monitoring and firm performance', Academy of Management Journal, Vol.37 No.4, pp.1002-1016.

Tosi Jr., H. L., Werner, S., Katz, J. P. and Gomez-Mejia, L R. (2000) 'How much does performance matter? A meta-analysis of CEO pay studies', Journal of Management Vol.26 No.2, pp.301-339.

van Essen, M., Heugens, P., Otten, J. and van Oosterhout, J. (2012) 'An institution-based view of executive compensation: A multilevel meta-analytic test', Journal of International Business Studies, Vol.43, pp.396-423.

van Essen, M., Otten, J. and Carberry, E. J. (2015) 'Assessing managerial power theory: A meta-analytic approach to understanding the determinants of CEO compensation', Journal of Management, Vol.41 No.1, pp.164-202.

Wade, J. B., Porac, J. F. and Pollock, T. G. (1997) 'Worth, words, and the justification of executive pay', Journal of Organizational Behavior, Vol.18 No.S1, pp.641-664.

Westphal, J. D. and Graebner, M. E. (2010) 'A matter of appearances: How corporate leaders manage the impressions of financial analyst about the conduct of their boards', Academy of Management Journal, Vol.53 No.1, pp.15-43.

Westphal, J. D. and Park, S. H. (2012) 'Unintended agency: Impression management support as a trigger of institutional change in corporate governance', Research in Organizational Behavior, Vol.32, pp.23-46.

Westphal, J. D. and Zajac, E. J. (1998) 'The symbolic management of stockholders: Corporate governance reform and shareholder reactions', Administrative Science Quarterly, Vol.43 No.1, pp.127-153.

Westphal, J. D. and Zajac, E. J. (2013) 'A behavioral theory of corporate governance: Explicating the mechanisms of socially situated and socially constituted agency', Academy of Management Annals, Vol.7 No.1, pp.607-661.

Wilkins, A. M., Hermanson, D. R. and Cohen, J. R. (2015) 'Do compensation committee members perceive changing CEO incentive performance targets mid-cycle to be fair?', Journal of Business Ethics, forthcoming, pp.1-16.

Wiseman, R. M., Cuevas-Rodriguez, G. and Gomez-Mejia, L. R. (2012) 'Towards a social theory of agency', Journal of Management Studies, Vol.49 No.1, pp.202-222.

Zajac, E. J. (1990) 'CEO selection, succession, compensation and firm performance: A theoretical integration and empirical analysis', Strategic Management Journal, Vol.11 No.3, pp.217-230.

Zajac, E. J. and Westphal, J. D. (1995) 'Accounting for the explanations of CEO compensation: Substance and symbolism', Administrative Science Quarterly, Vol.40 No.2, pp.283-308.

Zajac, E. J. and Westphal, J. D. (2004) 'The social construction of market value: Institutionalization and learning perspectives on stock market reactions', American Sociological Review, Vol.69 No.3, pp.433-457. 
Table 1: Remuneration Principles

\section{Remuneration Principles}

1. Market principle: An executive's remuneration should be set relative to that of other executives, particularly those in comparable positions, so that there is a degree of horizontal equity between executives.

2. Human resources principle: To attract and retain talented executives, their preferences and expectations should be taken into account when negotiating their remuneration packages and setting the level of remuneration.

3. Fairness principle: An executive's remuneration should be set relative to other employees in the organisation, so that there is a degree of vertical equity from the highest to lowest paid employee.

4. Pay-for-performance principle: An executive's remuneration should be tied to firm performance.

5. Strategic pay principle: An executive's remuneration should be tied to the firm's strategy (i.e. long-term objectives).

6. Balanced measurement principle: The performance measures, on which an executive's remuneration is contingent,
The market principle does not (1) account for an executive's contribution to firm performance, (2) specify the meaning of relative or comparable (i.e. should all executives in a peer group receive the same level of remuneration?); (3) specify if all elements of pay should be comparable (e.g. salary and/or bonuses); (4) specify how the peer group of any given executive is to be decided (e.g. internal or external peers, firms in similar industry, etc.); and (5) specify if comparisons should be direct or scaled/adjusted in some manner (e.g. job-sizing methods).

The human resources principle assumes that money constitutes a major part of executives' preferences and expectations, but offers no further insight. The notion that executives possess "special" knowledge and skills that are uncommon among the general population is reinforced (i.e. there is a limited supply of executives). No guidance is given on what level of remuneration is necessary to attract and retain executives (e.g. upper quartile relative to a peer group). Further, the negotiating position of boards is weakened as they do not want to lose talented executives.

The fairness principle links the remuneration of executives and employees, acting as a constraint on executive remuneration. However, the ratio between the highest and lowest paid employee is unspecified. How to determine this ratio is also unspecified. Having an unchanging ratio limits the possible actions of executives as, for example, they may be unwilling to pursue a cost reduction strategy that would lower the pay of employees and, consequently, themselves.

The pay-for-performance principle assumes that there is a direct link between an executive's actions and firm performance. It does not specify (1) how firm performance should be measured (e.g. profit growth, total shareholder return, etc.); (2) whether firm performance should be measured in absolute or relative terms; (3) the time period over which firm performance should be measured; (4) how an executive's contribution to firm performance can be quantified; and (5) how to set target(s) for an executive (e.g. should targets be realistic or challenging given recent trends in firm performance?).

The strategic pay principle is an extension of the pay-for-performance principle, where firm performance is defined by its strategy. Thus, the above comments are also applicable.

The balanced measurement principle is an extension of the pay-for-performance principle, where firm performance is measured using a range of financial and non-financial metrics. However, this principle does not specific how performance measures are to be selected and whether or not 


\begin{tabular}{|c|c|}
\hline $\begin{array}{l}\text { should include a range of financial and } \\
\text { non-financial metrics. }\end{array}$ & rics. \\
\hline $\begin{array}{l}\text { 8. Alignment principle: } \\
\text { remuneration, particularly equity-based } \\
\text { schemes, should be used to align the } \\
\text { interests of executives with those of } \\
\text { shareholders. }\end{array}$ & $\begin{array}{l}\text { The alignment principle is an extension of the pay-for-performance principle, where firm } \\
\text { performance is defined in terms of shareholders' interests. It assumes that shareholders' interests } \\
\text { are paramount, homogeneous and measurable (e.g. relative total shareholder return). It also } \\
\text { assumes that executives will not act in the best interests of shareholders in the absence of } \\
\text { variable remuneration. }\end{array}$ \\
\hline $\begin{array}{l}\text { 9. Motivation principle: } \text { Variable } \\
\text { remuneration should be used to motivate } \\
\text { an executive to maximise his/her effort. }\end{array}$ & $\begin{array}{l}\text { The motivation principle is the assumption underlying the pay-for-performance principle. } \\
\text { Executives are assumed to be primarily motivated by monetary rewards, rather than other } \\
\text { extrinsic and intrinsic rewards. It is also assumed that the effort of executives will be lower or } \\
\text { misdirected in the absence of variable remuneration. }\end{array}$ \\
\hline $\begin{array}{l}\text { 10. Ability-to-pay principle: The board (or } \\
\text { remuneration committee) should take the } \\
\text { firm's financial position into account } \\
\text { when deciding on an executive's potential } \\
\text { and actual remuneration. }\end{array}$ & $\begin{array}{l}\text { The ability-to-pay principle states that the board (or remuneration committees) has a } \\
\text { responsibility to ensure that executive remuneration, both potential and actual, is not excessive or } \\
\text { beyond the means of the firm. However, how the affordability of executive remuneration is to be } \\
\text { determined is unspecified. This principle does not account for the impact of actual executive } \\
\text { remuneration on shareholders' wealth (e.g. executive stock options dilute the share price). }\end{array}$ \\
\hline $\begin{array}{l}\text { 11. Conformance principle: The board (or } \\
\text { remuneration committee) should take best } \\
\text { practice, regulations and the legitimate } \\
\text { interests of stakeholders into account } \\
\text { when deciding on executive } \\
\text { remuneration. }\end{array}$ & $\begin{array}{l}\text { The conformance principle states that the board (or remuneration committee) should take societal } \\
\text { expectations and norms into account when making decisions, although the board will have to } \\
\text { define societal expectations and norms. The meaning of 'best practice' and 'the legitimate } \\
\text { interests of stakeholders' are open to interpretation; non-shareholding stakeholders may still be } \\
\text { treated as a means to the end of shareholder value. Also, the meaning of 'take into account' is } \\
\text { open to interpretation, placing no explicit obligation on the board. }\end{array}$ \\
\hline $\begin{array}{l}\text { 12. Independence principle: An executive } \\
\text { should not be involved in the setting of } \\
\text { his/her own remuneration. Therefore, the } \\
\text { remuneration committee should be } \\
\text { comprised of a majority of independent }\end{array}$ & $\begin{array}{l}\text { The independence principle assumes that (1) executives would act in an opportunistic manner if } \\
\text { they are able to set their own remuneration, and (2) independent non-executive directors are able } \\
\text { to make better decisions about executive remuneration than any other group. However, } \\
\text { independence is not defined and usually does not exclude social ties between executives and } \\
\text { non-executive directors. Further, experience in human resources management is not an explicit }\end{array}$ \\
\hline
\end{tabular}


non-executive directors.

13. Consultant principle: The board (or remuneration committee) should seek advice from specialist, independent remuneration consultants when making decisions on executive remuneration.

14. Transparency principle: The board (or remuneration committee) should disclose the firm's remuneration policies and practices.

\section{prerequisite for being a member of the remuneration committee.}

The consultant principle is related to the market and independence principles. This principle (1) assumes that consultants do not have vested interests in the data and advice they provide to the board, (2) does not restrict the methods for collecting and analysing data which consultants may use (e.g. direct comparison, scaled comparison, job-sizing, etc.), and (3) does not specify how the board should select consultants.

The transparency principle assumes that shareholders and the public have a right to know the firm's remuneration policies and practices. The board still has discretion in deciding how much detail about executive remuneration to disclose (e.g. specific performance measures may not be disclosed, so that competitors do not know the firm's strategic priorities). 
Table 2: Prevalence of Remuneration Principles in Qualitative Research

\begin{tabular}{|c|c|c|c|c|}
\hline $\begin{array}{l}\text { Remuneration } \\
\text { Principles }\end{array}$ & $\begin{array}{c}\text { Agreement } \\
\text { (out of 45) }\end{array}$ & $\begin{array}{l}\text { Disagreement } \\
\text { (out of 45) }\end{array}$ & Examples of Agreement & Examples of Disagreement \\
\hline $\begin{array}{l}\text { 2. Human } \\
\text { resources } \\
\text { principle }\end{array}$ & 18 & 1 & $\begin{array}{l}\text { Bender (2011b, p.18): A company } \\
\text { chairperson explained, "We clearly in this } \\
\text { particular case went beyond what we had } \\
\text { established as at that level of the } \\
\text { organisation. But given the strategic } \\
\text { importance of the project he was going to } \\
\text { lead, the value that he brought to the } \\
\text { company over and above what the job } \\
\text { specified, we said well there is clearly a } \\
\text { premium in there and we want the man, so } \\
\text { what is he worth?" }\end{array}$ & $\begin{array}{l}\text { Morris and Fenton-O'Creevy }(1996, \mathrm{p} .712) \text { : } \\
\text { In the case company, } 28 \% \text { of participants } \\
\text { disagreed and } 18 \% \text { of participants were } \\
\text { neutral to the following statement, "The } \\
\text { compensation package... provides an } \\
\text { effective incentive to stay with this } \\
\text { organization." }\end{array}$ \\
\hline $\begin{array}{l}\text { 3. Fairness } \\
\text { principle }\end{array}$ & 6 & 3 & $\begin{array}{l}\text { Malsch et al. (2012, p.410): A member of the } \\
\text { compensation committee argued, "I think fair } \\
\text { has to do with treating the whole } \\
\text { organization as decently as you can in terms } \\
\text { of fair income... I hate it when I see a CEO } \\
\text { earning much more than his direct reports. I }\end{array}$ & $\begin{array}{l}\text { Bender and Moir (2006, p.82): A committee } \\
\text { chair commented, "Oh, I don't think we've } \\
\text { got those sort of formula [relating executive } \\
\text { pay to average or minimum wages] in place. } \\
\text { Because I think the top end is driven by } \\
\text { assessment of what the market would pay for }\end{array}$ \\
\hline
\end{tabular}




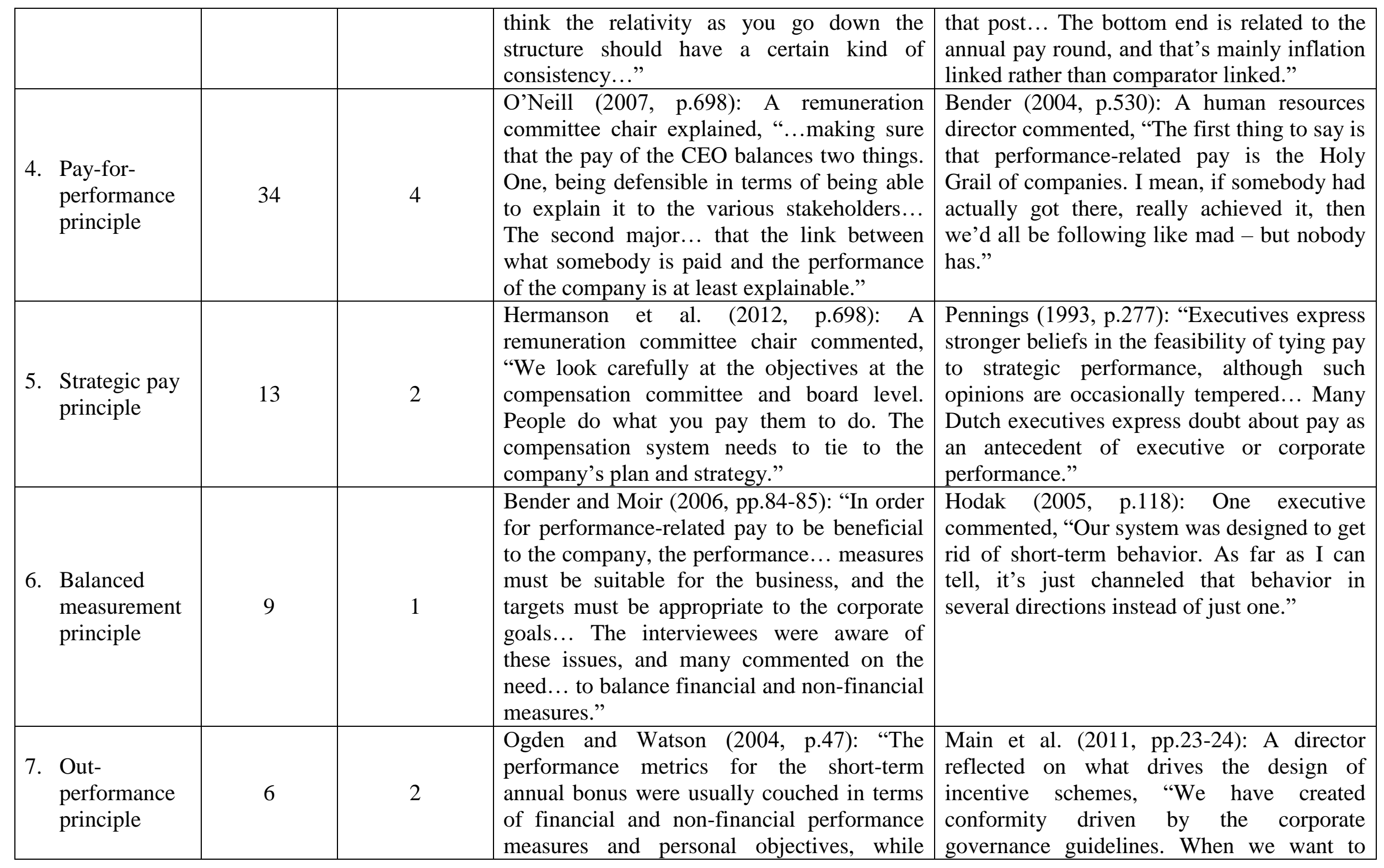




\begin{tabular}{|c|c|c|c|c|}
\hline & & & $\begin{array}{l}\text { those for the LTIPs were specified } \\
\text { exclusively in terms of financial } \\
\text { performance, usually measured in terms of } \\
\text { total shareholder return. All the interviewees } \\
\text { were confident that the targets set for } \\
\text { performance were challenging and stretched } \\
\text { the executive directors." }\end{array}$ & $\begin{array}{l}\text { create something new, for example, profit } \\
\text { share or private equity style plans, it can } \\
\text { make it very difficult. Executives are cynical } \\
\text { about performance conditions but investors } \\
\text { want stretching targets - this means that we } \\
\text { have conformed to a certain type, and the } \\
\text { question is do they really incentivise and } \\
\text { influence behaviours or are they just } \\
\text { expected?" }\end{array}$ \\
\hline $\begin{array}{l}\text { 10. Ability-to-pay } \\
\text { principle }\end{array}$ & 3 & 0 & $\begin{array}{l}\text { Chapman and Kelliher (2011, p.131): "The } \\
\text { significance of the effective management of } \\
\text { reward mix for cost management purposes } \\
\text { was raised by all interviewees... [This is } \\
\text { illustrated by one consultant's comment on a }\end{array}$ & --- \\
\hline
\end{tabular}




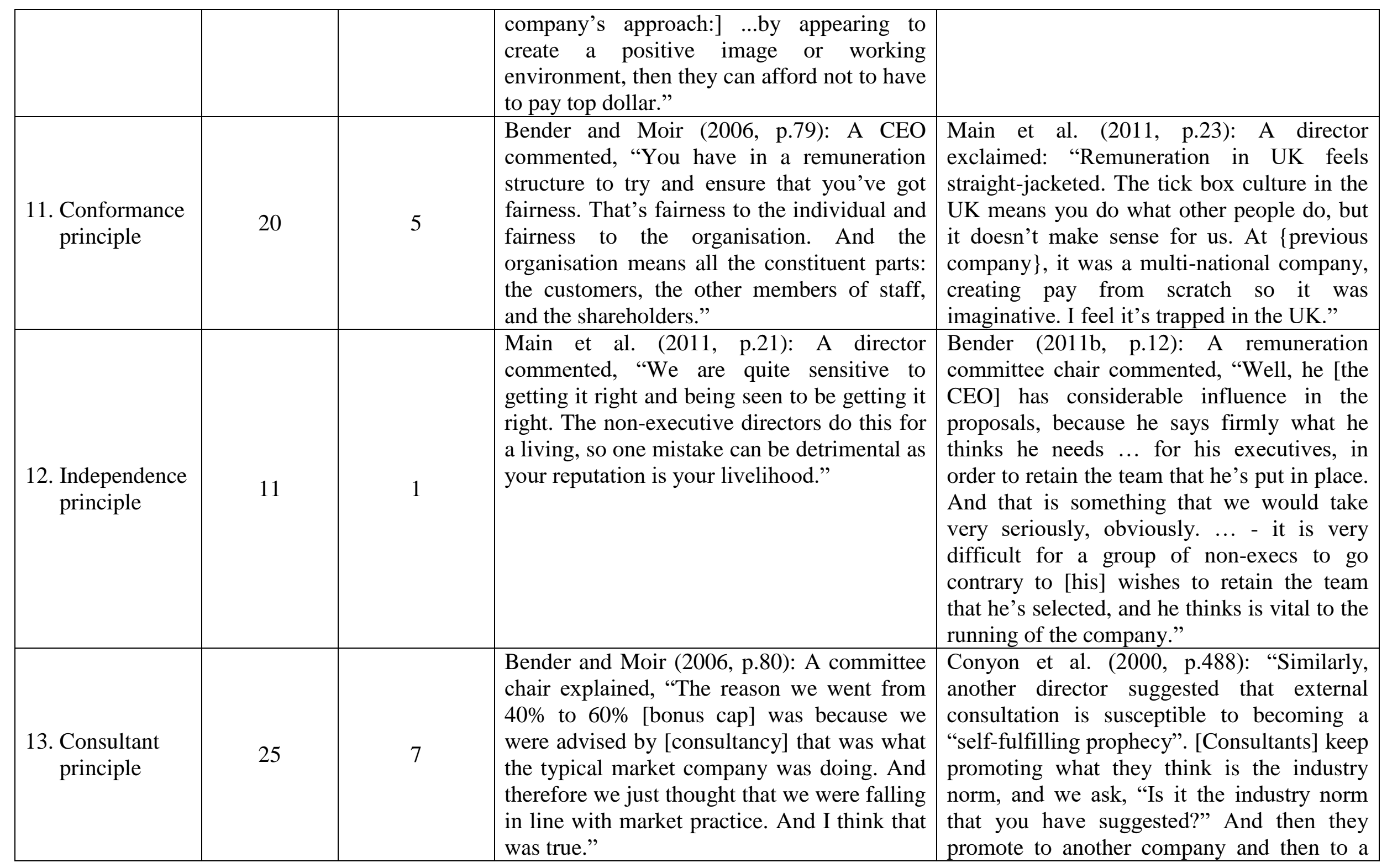




\begin{tabular}{|c|c|c|c|c|}
\hline & & & & $\begin{array}{l}\text { third company... so it's become an industry } \\
\text { norm. We are very suspicious of that." }\end{array}$ \\
\hline
\end{tabular}


Table 3: Remuneration Principles and Practices

\begin{tabular}{|c|c|c|}
\hline Remuneration Practices & Remuneration Principles & Selected Findings from Prior Studies \\
\hline $\begin{array}{l}\text { Base salary and benefits } \\
\text { - Level: Set relative to a } \\
\text { peer group (e.g. } \\
\text { median or upper } \\
\text { quartile) } \\
\text { Peer group: Selected } \\
\text { competitors, industry } \\
\text { or stock exchange } \\
\text { index }\end{array}$ & $\begin{array}{l}\text { - Remuneration committees typically set executives' } \\
\text { base salary and benefits at the median to upper } \\
\text { quartile relative to a peer group, and this is justified } \\
\text { using the market, human resources and consultant } \\
\text { principles (e.g. Bender, 2007; Clarke et al., 1998; } \\
\text { Ogden and Watson, 2012). } \\
\text { - The fairness, pay-for-performance and conformance } \\
\text { principles may act as constraints on increases in base } \\
\text { salary and benefits (Morris and Fenton-O'Creevy, } \\
\text { 1996). }\end{array}$ & $\begin{array}{l}\text { - Ogden and Watson }(2012, \text { p.513): "For example, a } \\
\text { member of Alpha's Remco commented: ...there is a } \\
\text { huge amount of comparison... But you still have to } \\
\text { decide what salary you pay somebody - has the } \\
\text { bloke really performed in the year? ...Whatever the } \\
\text { benchmarks say, you've still got to say: what is his } \\
\text { contribution?" }\end{array}$ \\
\hline $\begin{array}{l}\text { Pension or superannuation } \\
\text { - Type of scheme: } \\
\text { Defined benefit (e.g. } \\
\text { percentage of salary } \\
\text { upon retirement) or } \\
\text { defined contribution }\end{array}$ & $\begin{array}{l}\text { - There is scant qualitative research on pensions, aside } \\
\text { from odd comment that remuneration committees } \\
\text { take advice on the tax implications of schemes } \\
\text { (Chapman and Kelliher, 2011) and disclosure of } \\
\text { schemes has become best practice (Kovacevic, } \\
\text { 2009). } \\
\text { - It is likely that pension schemes will be justified } \\
\text { using the market, human resources, ability-to-pay, } \\
\text { conformance and consultant principles. }\end{array}$ & $\begin{array}{l}\text { - Chapman and Kelliher }(2011, \text { p.127): A consultant } \\
\text { explained, "I have had conversations with FDs } \\
\text { [finance directors] who have dismissed the need to } \\
\text { do anything about DC [defined contribution] } \\
\text { engagement because they just don't see the point } \\
\text { its increased costs for the company..." }\end{array}$ \\
\hline $\begin{array}{l}\text { Short-term incentives } \\
\text { - Level: Multiple } \\
\text { salary }\end{array}$ & $\begin{array}{l}\text { - Qualitative research on executive remuneration has } \\
\text { tended to discuss variable remuneration in general } \\
\text { terms or with respect to long-term incentives, rather }\end{array}$ & $\begin{array}{l}\text { Penning }(1993, \text { p.272): “...bonuses ...presume } \\
\text { flexibility in tying pay to performance. Since variable } \\
\text { pav makes for a more immediate connection, }\end{array}$ \\
\hline
\end{tabular}




\begin{tabular}{|c|c|c|}
\hline $\begin{array}{llr}\text { - } & \text { Measures: Financial } \\
\text { and/or non-financial; } \\
\text { Internal and/or } \\
\text { external } \\
\text { Target: Absolute } \\
\text { and/or relative } \\
\text { - Type: Cash and/or } \\
\text { shares } \\
\text { Timing: Immediate } \\
\text { and/or deferred }\end{array}$ & $\begin{array}{l}\text { than short-term incentives. } \\
\text { The market, human resources, pay-for-performance, } \\
\text { strategic pay, balanced measurement, alignment, } \\
\text { motivation and conformance principles provide a } \\
\text { framework for short-term incentive schemes (e.g. } \\
\text { Bender, 2004, 2007; Hermanson et al., 2012; Main et } \\
\text { al., 2008). } \\
\text { - Applying the principles may result in conflicts that } \\
\text { the remuneration committee has to manage. The } \\
\text { market and human resources principles put upward } \\
\text { pressure on the level of pay, while the pay-for- } \\
\text { performance (e.g. during a recession) and fairness } \\
\text { principles may put downward pressure on the level } \\
\text { of pay (Hermanson et al., 2012). }\end{array}$ & $\begin{array}{l}\text { individuals attribute a greater motivational effect to } \\
\text { it, at least among US executives in several } \\
\text { industries." } \\
\text { - Bender and Moir (2006, p.82): "The short-term } \\
\text { element, normally an annual bonus scheme, will } \\
\text { often include both corporate and individual } \\
\text { performance targets." } \\
\text { - Pepper et al. (2013, pp.41-42): "Short-term } \\
\text { incentives (annual bonuses) were generally regarded } \\
\text { as very effective by executives and non-executives } \\
\text { alike. Participants described them, in comparison } \\
\text { with long-term incentives, as having much better } \\
\text { 'line of sight', meaning that the connection between } \\
\text { successful actions and reward was more obvious." }\end{array}$ \\
\hline $\begin{array}{l}\text { Long-term incentives } \\
\text { - Level: Multiple of } \\
\text { salary } \\
\text { Measures: Financial } \\
\text { and/or non-financial; } \\
\text { Internal and/or } \\
\text { external } \\
\text { Target: Absolute and/ } \\
\text { or relative } \\
\text { Testing: When } \\
\text { awarded and/or at } \\
\text { vesting } \\
\text { Type: Cash, options } \\
\text { and/or shares } \\
\text { Length of vesting } \\
\text { period (e.g. 3-10 } \\
\text { years) }\end{array}$ & $\begin{array}{l}\text { - Qualitative research has found that remuneration } \\
\text { committees use a range of remuneration principles to } \\
\text { justify long-term incentive schemes (e.g. Bender, } \\
\text { 2004; Hermanson et al., 2012; Ogden and Watson, } \\
\text { 2008; Pepper et al., 2013). } \\
\text { - For example, St-Onge et al. (2001) found that } \\
\text { executives provided five different justifications for } \\
\text { having stock option plans. These justifications were } \\
\text { consistent with the alignment, conformance, human } \\
\text { resources, motivation and pay-for-performance } \\
\text { principles. } \\
\text { However, there are conflicts between the principles } \\
\text { (as described under short-term incentives). Using } \\
\text { long-term incentives as means of attracting and } \\
\text { retaining talent is consistent with the human resource } \\
\text { principles, but may conflict with the alignment and } \\
\text { pay-for-performance principles. }\end{array}$ & $\begin{array}{l}\text { - Main et al. (2008, p.230): A remuneration committee } \\
\text { chair explained, "The obvious metrics of EPS and } \\
\text { TSR are catch-alls but it's where you always end } \\
\text { up". } \\
\text { - Pepper et al. (2013, p.42): "Long-term incentive } \\
\text { plans, on the other hand, were generally seen as at } \\
\text { best only partially effective; indeed, many of the } \\
\text { executives in our study felt that LTIPs failed to meet } \\
\text { their main objectives. Various reasons were given } \\
\text { for this. Commonly cited was the complexity of most } \\
\text { LTIPs... A specific problem that participants } \\
\text { identified with LTIPs was the use of comparative } \\
\text { performance measures, such as relative total } \\
\text { shareholder return (TSR). As one CEO said, "I don't } \\
\text { know how to manage relative TSR . . . you don't } \\
\text { wake up in the morning trying to manage something } \\
\text { relative"." }\end{array}$ \\
\hline Minimum sha & There is scant qualitative resea & Bender (2007) \\
\hline
\end{tabular}




\begin{tabular}{|c|c|c|}
\hline $\begin{array}{l}\text { requirement } \\
\text { - Level: Multiple of } \\
\text { salary }\end{array}$ & $\begin{array}{l}\text { shareholding requirement for executives (cf. Bender, } \\
\text { 2007). } \\
\text { It is likely that a minimum shareholding requirement } \\
\text { will be justified using the alignment and } \\
\text { conformance principles. It may also be justified } \\
\text { using the human resources principle (Bender, 2007). }\end{array}$ & $\begin{array}{l}\text { practices in } 12 \text { UK companies. One of these changes } \\
\text { involved the introduction of a minimum } \\
\text { shareholding requirement in order to financially tie } \\
\text { executives to the company and lessen the chance of } \\
\text { them leaving the company. }\end{array}$ \\
\hline $\begin{array}{l}\text { Mix of fixed and variable } \\
\text { - From mainly fixed to } \\
\text { mainly variable }\end{array}$ & $\begin{array}{l}\text { The mix of fixed and variable remuneration has not } \\
\text { been specifically studied by qualitative researchers. } \\
\text { However, the diffusion of the alignment, motivation } \\
\text { and pay-performance principles are likely to have } \\
\text { been influential in the shift from mainly fixed to } \\
\text { mainly variable remuneration (e.g. compare } \\
\text { Pennings, } 1993 \text { and Bender, 2007). }\end{array}$ & $\begin{array}{l}\text { - Conyon et al. (2000, p.489): "One director claimed } \\
\text { good practice in long-term compensation as being: a } \\
\text { salary much lower in proportion to the whole, a } \\
\text { benefit package substantially less attractive than } \\
\text { what is available here, but with enormous so-called } \\
\text { incentive elements..." }\end{array}$ \\
\hline $\begin{array}{l}\text { Level of fixed, variable } \\
\text { and total } \\
\text { - Level: Set relative to a } \\
\text { peer group (e.g. } \\
\text { median or upper } \\
\text { quartile) } \\
\text { - Peer group: Selected } \\
\text { competitors, industry } \\
\text { or stock exchange } \\
\text { index }\end{array}$ & $\begin{array}{l}\text { While the alignment, motivation, pay-for- } \\
\text { performance principles influence how executives are } \\
\text { paid, the human resources and market principles } \\
\text { influence how much they are paid (e.g. Main, 1993; } \\
\text { Ogden and Watson, 2004, 2012; Perkins and } \\
\text { Hendry, 2005). The combination of the human } \\
\text { resources and market principles may result in ever- } \\
\text { increasing levels of pay as remuneration committees } \\
\text { believe their executives possess above-average } \\
\text { capabilities, deserving of above-average pay. } \\
\text { - Surprisingly, the ability-to-pay principle is rarely } \\
\text { mentioned in qualitative research. }\end{array}$ & $\begin{array}{l}\text { - Ogden and Watson }(2012, \text { p.515): “As one } \\
\text { interviewee put it: 'If the total package isn't good } \\
\text { enough, they [the executives] will just move } \\
\text { somewhere else, won't they."” }\end{array}$ \\
\hline
\end{tabular}


Figure 1: Remuneration Decision-Making and Influential Parties

(Source: Crombie, 2013, p.107)

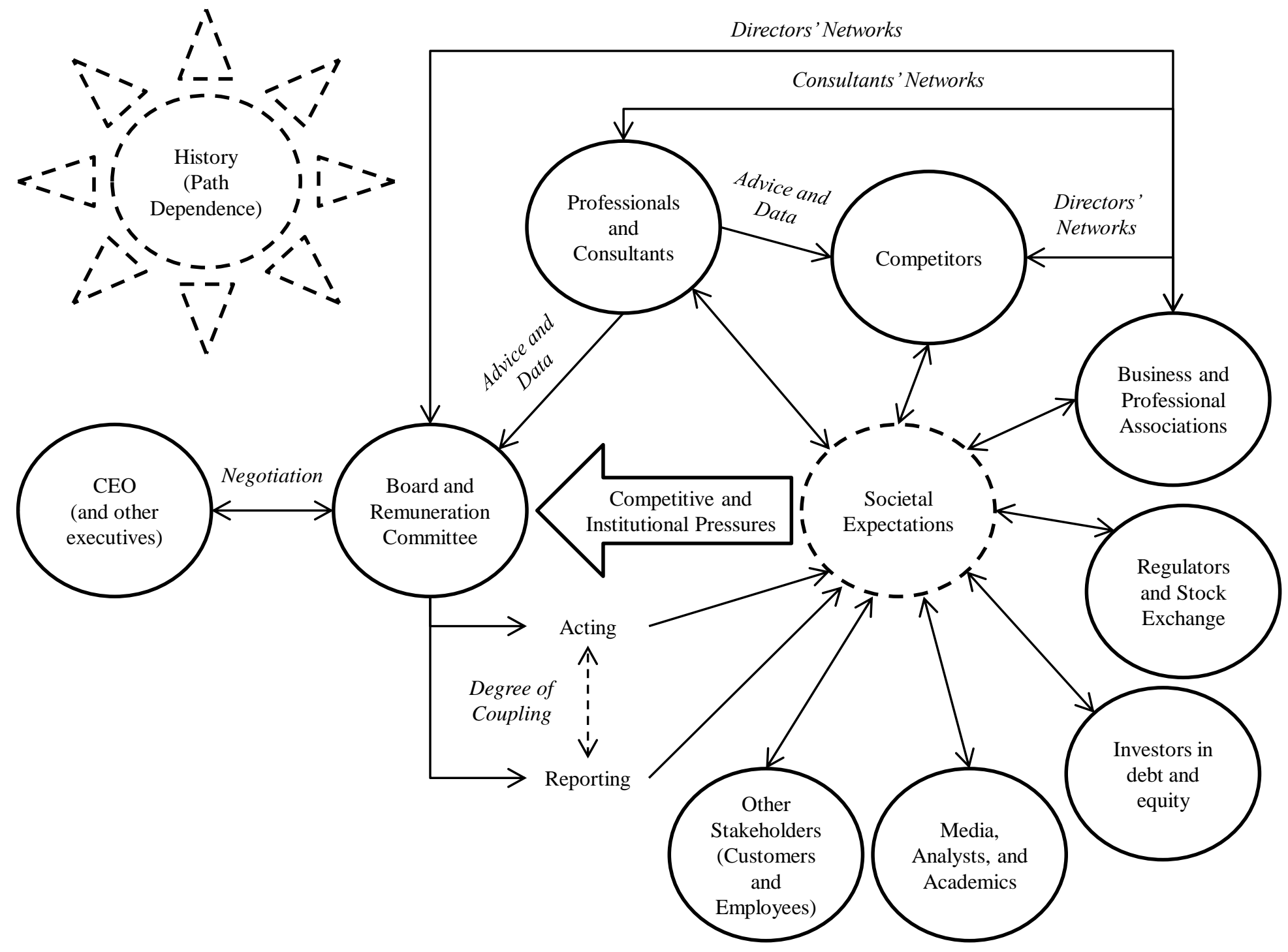




\section{Appendix A: Prevalence of Remuneration Principles in Qualitative Research}

This appendix presents a brief summary of qualitative research on executive remuneration including studies that surveyed and interviewed executives, non-executive directors and others (e.g. remuneration consultants) as well as studies that analysed remuneration disclosures in corporate annual reports. Table 4 presents a summary of the research methods, findings and prevalence of remuneration principles from 45 studies. The focus of prior research has not been to identify remuneration principles or to find evidence that supports or reputes remuneration principles. This meant that there was a high degree of subjectivity in quantifying the prevalence of the remuneration principles. The studies reviewed were read at least twice by this researcher and keyword searchers were also used to identify the presence or absence of the remuneration principles. Note that the presence or absence of the remuneration principles relates to the participants' beliefs about executive remuneration, not the authors' beliefs. No judgement was made regarding the strength of agreement or disagreement with the remuneration principles in the studies reviewed. Therefore, the ticks $(\checkmark)$ and crosses $(\mathbf{X})$ presented Table 4 should be interpreted with caution.

Notes to Table 4:

$\checkmark$ - A tick indicates that the participants in the study supported or agreed with a particular remuneration principle.

$\mathbf{X}$ - A cross indicates that the participants in the study criticised or disagreed with a particular remuneration principle.

1. Market principle

2. Human resources principle

3. Fairness principle

4. Pay-for-performance principle

5. Strategic pay principle

6. Balanced performance measurement principle

7. Out-performance principle

8. Alignment principle

9. Motivation principle

10. Ability-to-pay principle

11. Conformance principle

12. Independence principle

13. Consultant principle

14. Transparency principle 
a. Tosi and Gomez-Mejia's $(1989 ; 1994)$ composite variable, "monitoring”, is based on 17 items in a questionnaire. These items relate to 7 remuneration principles. However, they did not report descriptive statistics for each of the 17 items, only the monitoring variable. From the statistics reported, it is evidence that there is strong support for the 17 items (with high factor loadings). It is likely that the respondents expressed a range of opinions about the 17 items (as represented on a 1-5 Likert scale). Nevertheless, no crosses are indicated in the table due to the lack of information.

b. Morris and Fenton-O'Creevy (1996) did not report descriptive statistics for items in a questionnaire relating to the market, fairness and payfor-performance principles. While it is likely that some respondents disagreed with the items, no crosses are indicated in the table for these principles due to a lack of information.

c. Bart et al. (2011) did not report in-depth descriptive statistics for the items in a questionnaire relating to the market, pay-for-performance, independence, consultant and transparency principles. While it is likely that some respondents disagreed with the items, no crosses are indicated in the table for these principles due to a lack of information.

d. Wilkins et al.'s (2015) definition of fairness differs from that put forward in this paper. They defined fairness in terms of process and outcome for the CEO and shareholders, rather than the relationship between CEO and employee pay.

Table 4: Summary of Qualitative Research on Executive Remuneration

\begin{tabular}{|c|c|c|c|c|c|c|c|c|c|c|c|c|c|c|c|c|}
\hline \multirow[t]{4}{*}{ Study } & \multirow[t]{4}{*}{ Method } & Remuneration Principles & 1 & 2 & 3 & 4 & 5 & 6 & 7 & 8 & 9 & 10 & 11 & 12 & \begin{tabular}{|l|}
13 \\
\end{tabular} & 14 \\
\hline & & Number of ticks $(\checkmark)$ & 25 & 18 & 6 & 34 & 13 & 9 & 6 & 14 & 24 & 3 & 20 & 11 & 25 & 7 \\
\hline & & Number of crosses $(\mathbf{X})$ & 6 & 1 & 3 & 4 & 2 & 1 & 2 & 2 & 8 & 0 & 5 & 1 & 7 & 5 \\
\hline & & Summary of Relevant Findings & & & & & & & & & & & & & & \\
\hline $\begin{array}{l}\text { Tosi and Gomez- } \\
\text { Mejia }(1989)^{\mathrm{a}}\end{array}$ & $\begin{array}{l}\text { Survey of } 175 \text { Chief } \\
\text { Compensation Officers } \\
\text { from US manufacturing } \\
\text { companies. }\end{array}$ & $\begin{array}{l}\text { Owner-controlled firms put greater emphasis on a } \\
\text { variable pay philosophy than management- } \\
\text { controlled firms. }\end{array}$ & & & & $\checkmark$ & $\checkmark$ & $\checkmark$ & & $\checkmark$ & $\checkmark$ & $\checkmark$ & $\checkmark$ & $\checkmark$ & $\checkmark$ & \\
\hline Zajac (1990) & 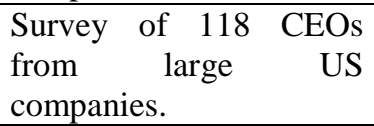 & $\begin{array}{l}\text { CEOs satisfied with their pay, perceived a link } \\
\text { between their wealth and firm wealth, and their } \\
\text { reputation and firm wealth. }\end{array}$ & & & & $\checkmark$ & & & & & & & & & & \\
\hline Main (1993) & $\begin{array}{l}\text { Interviews with } 24 \\
\text { directors and executives } \\
\text { from large UK } \\
\text { companies. }\end{array}$ & $\begin{array}{l}\text { Focused on remuneration practices and processes, } \\
\text { rather than remuneration principles. }\end{array}$ & $\checkmark$ & & & $\checkmark$ & & & & & & & & $\checkmark$ & $\begin{array}{l}\checkmark \\
x\end{array}$ & $\checkmark$ \\
\hline Pennings (1993) & $\begin{array}{l}\text { Interviews (1985-1988) } \\
\text { with } 51 \text { US executives, } 5 \\
\text { French executives and } \\
11 \text { Dutch executives } \\
\text { from large companies. }\end{array}$ & $\begin{array}{l}\text { There was a range of opinions: Some believed that } \\
\text { executives can influence firm performance and } \\
\text { monetary incentives can motivate executives, while } \\
\text { others did not; country and industry influenced } \\
\text { executives' beliefs. }\end{array}$ & $\checkmark$ & & $\checkmark$ & $\begin{array}{l}\checkmark \\
\times\end{array}$ & $\begin{array}{l}\checkmark \\
\times\end{array}$ & $\checkmark$ & $\checkmark$ & & $\begin{array}{l}\checkmark \\
\times\end{array}$ & & & & & \\
\hline Tosi and Gomez- & Survey of 243 Chief & Owner-controlled firms put greater emphasis on a & & & & $\checkmark$ & $\checkmark$ & $\checkmark$ & & $\checkmark$ & $\checkmark$ & $\checkmark$ & & $\checkmark$ & $\checkmark$ & \\
\hline
\end{tabular}




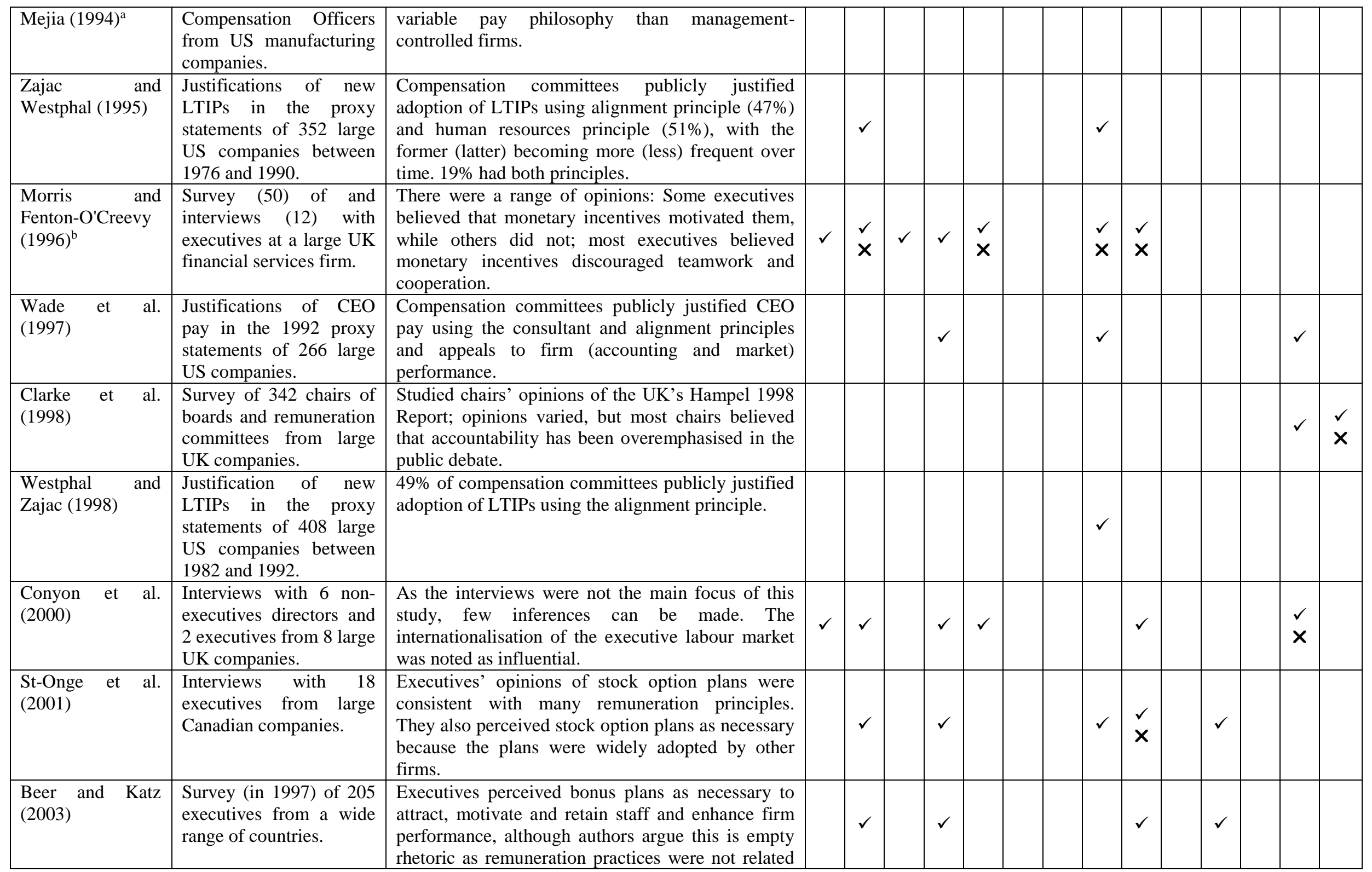




\begin{tabular}{|c|c|c|c|c|c|c|c|c|c|c|c|c|c|c|c|}
\hline & & to firm performance. & & & & & & & & & & & & & \\
\hline Bender (2003) & $\begin{array}{l}\text { Interviews with } 11 \\
\text { people from } 2 \text { UK } \\
\text { utilities including non- } \\
\text { executives directors, } \\
\text { executives and external } \\
\text { consultants. }\end{array}$ & $\begin{array}{l}\text { Interviewees' opinions were consistent with many } \\
\text { of the remuneration principles; they had an } \\
\text { optimistic view of executives, with a strong } \\
\text { emphasis on using remuneration to attract and retain } \\
\text { executives. }\end{array}$ & $\checkmark$ & $\checkmark$ & & $\checkmark$ & $\checkmark$ & & & & $\checkmark$ & $\checkmark$ & & $\checkmark$ & \\
\hline Bender (2004) & $\begin{array}{l}\text { Interviews with } 30 \\
\text { directors and executives } \\
\text { from } 5 \text { large UK } \\
\text { companies as well as } 5 \\
\text { of their consultants. }\end{array}$ & $\begin{array}{l}\text { Interviewees' opinions were consistent with most of } \\
\text { the remuneration principles; they had an optimistic } \\
\text { view of executives, where incentives provided } \\
\text { strategic focus; there were mixed views on the } \\
\text { motivation principle. }\end{array}$ & $\checkmark$ & $\checkmark$ & $\checkmark$ & $\begin{array}{l}\checkmark \\
x\end{array}$ & $\checkmark$ & $\checkmark$ & & $\checkmark$ & $\begin{array}{l}\checkmark \\
x\end{array}$ & $\checkmark$ & & $\checkmark$ & \\
\hline $\begin{array}{l}\text { Franco-Santos et } \\
\text { al. }(2004)\end{array}$ & $\begin{array}{l}\text { Survey of } 117 \text { executives } \\
\text { from large UK } \\
\text { companies. }\end{array}$ & $\begin{array}{l}\text { Executives perceived performance measurement } \\
\text { systems as providing strategic focus and, to a much } \\
\text { lesser extent, motivation. }\end{array}$ & & & & $\checkmark$ & $\checkmark$ & $\checkmark$ & & & $\checkmark$ & & & & \\
\hline $\begin{array}{l}\text { Ogden and } \\
\text { Watson (2004) }\end{array}$ & $\begin{array}{l}\text { Interviews with an } \\
\text { undisclosed number of } \\
\text { directors, who serve on } \\
\text { remuneration } \\
\text { committees, from } 4 \text { large } \\
\text { UK water utilities. }\end{array}$ & $\begin{array}{l}\text { Remuneration committees used consultants and } \\
\text { reviewed market comparisons, but the interviewees } \\
\text { felt they could resist market pressure to increase } \\
\text { pay; while the CEO was involved in determining } \\
\text { his/her pay, performance measures and targets, this } \\
\text { was not perceived to be an undue influence. }\end{array}$ & $\begin{array}{l}\checkmark \\
\times\end{array}$ & & & $\checkmark$ & & $\checkmark$ & $\checkmark$ & & & $\checkmark$ & $\checkmark$ & $\begin{array}{l}\checkmark \\
\times\end{array}$ & $\checkmark$ \\
\hline $\begin{array}{l}\text { Spira and Bender } \\
(2004)\end{array}$ & $\begin{array}{l}\text { Same data source as } \\
\text { Bender (2004) plus } \\
\text { interviews with audit } \\
\text { committee members. }\end{array}$ & $\begin{array}{l}\text { Remuneration committees and their consultants } \\
\text { have to work independently of management. }\end{array}$ & & & & & & & & & & & $\checkmark$ & $\checkmark$ & \\
\hline Hodak (2005) & $\begin{array}{l}\text { Survey and interview } \\
\text { data from an undisclosed } \\
\text { number of executives } \\
\text { and consultants. }\end{array}$ & $\begin{array}{l}\text { The author argues that simple pay-for-performance } \\
\text { schemes are the most effective and that companies } \\
\text { should only have one scheme. }\end{array}$ & & & & $\checkmark$ & $\checkmark$ & $\begin{array}{l}\checkmark \\
\times\end{array}$ & $\checkmark$ & $\begin{array}{l}\checkmark \\
x\end{array}$ & $\checkmark$ & $\checkmark$ & & $\checkmark$ & \\
\hline $\begin{array}{l}\text { Perkins and } \\
\text { Hendry (2005) }\end{array}$ & $\begin{array}{l}\text { Interviews with } 7 \text { non- } \\
\text { executive directors from } \\
\text { large UK companies and } \\
5 \quad \text { recruitment } \\
\text { consultants. }\end{array}$ & $\begin{array}{l}\text { The authors and interviewees critique the notion of } \\
\text { a labour market for executives, but using } \\
\text { comparative data is still the norm; money seen as a } \\
\text { scorecard for executives. }\end{array}$ & $\begin{array}{l}\checkmark \\
x\end{array}$ & & & $\checkmark$ & & & & & $\begin{array}{l}\checkmark \\
x\end{array}$ & & & $\checkmark$ & $\begin{array}{l}\checkmark \\
x\end{array}$ \\
\hline $\begin{array}{l}\text { Reilly and Scott } \\
(2005)\end{array}$ & $\begin{array}{l}\text { Interviews with } 21 \text { non- } \\
\text { executive directors from } \\
\text { US companies. }\end{array}$ & $\begin{array}{l}\text { The interviewees indicated they had a close } \\
\text { relationship with the CEO, despite being considered } \\
\text { independent; they also indicated that they would not } \\
\text { pay CEOs below the median relative to other CEOs. }\end{array}$ & $\begin{array}{l}\checkmark \\
x\end{array}$ & & & & & & & & & & $\checkmark$ & $\checkmark$ & \\
\hline
\end{tabular}




\begin{tabular}{|c|c|c|c|c|c|c|c|c|c|c|c|c|c|c|c|}
\hline $\begin{array}{l}\text { Bender and Moir } \\
(2006)\end{array}$ & $\begin{array}{l}\text { Interviews (2001-2003) } \\
\text { with } 30 \text { directors and } \\
\text { executives from } 5 \text { large } \\
\text { UK companies as well as } \\
5 \text { of their consultants. }\end{array}$ & $\begin{array}{l}\text { In setting executive remuneration, the interests of } \\
\text { executives and shareholders were paramount, } \\
\text { although the interests of customers and employees } \\
\text { may also be considered. Interviewees' opinions } \\
\text { were consistent with most remuneration principles, } \\
\text { although problems with several principles were } \\
\text { noted (particularly the market principle). }\end{array}$ & $\begin{array}{l}\checkmark \\
x\end{array}$ & $\checkmark$ & $\begin{array}{l}\checkmark \\
x\end{array}$ & $\checkmark$ & $\checkmark$ & $\checkmark$ & $x$ & $\checkmark$ & $\checkmark$ & $\checkmark$ & & $\checkmark$ & $x$ \\
\hline $\begin{array}{l}\text { Point and Tyson } \\
\text { (2006) }\end{array}$ & $\begin{array}{l}\text { Justifications of } \text { CEO } \\
\text { pay in the } 2002 \text { annual } \\
\text { reports of } 23 \text { large } \\
\text { European and } \mathrm{UK} \\
\text { companies. }\end{array}$ & $\begin{array}{l}\text { The sampled companies' remuneration policies } \\
\text { were consistent with many of the remuneration } \\
\text { principles; the authors argued that the companies } \\
\text { had adopted the language of corporate governance } \\
\text { codes. }\end{array}$ & & $\checkmark$ & & $\checkmark$ & & & & $\checkmark$ & $\checkmark$ & $\checkmark$ & & & $\checkmark$ \\
\hline Bender (2007) & $\begin{array}{l}\text { Interviews }(2001- \\
\text { 2003)with } 30 \text { directors } \\
\text { and executives from 5 } \\
\text { large UK companies as } \\
\text { well as } 5 \text { of their } \\
\text { consultants. }\end{array}$ & $\begin{array}{l}\text { Changes in executive remuneration practices were } \\
\text { made because current levels of pay were below the } \\
\text { market norms and practices were inconsistent with } \\
\text { strategy and best practice. }\end{array}$ & $\checkmark$ & $\checkmark$ & & $\checkmark$ & $\checkmark$ & & & & $\checkmark$ & $\checkmark$ & & & \\
\hline $\begin{array}{l}\text { Lawler and } \\
\text { Finegold (2007) }\end{array}$ & $\begin{array}{l}\text { Survey of } 768 \text { CEOs and } \\
\text { non-executive directors } \\
\text { of large US companies. }\end{array}$ & $\begin{array}{l}\text { Historical increases in CEO pay were perceived to } \\
\text { have resulted from the use of consultants, weak } \\
\text { boards, and adoption of new equity-based } \\
\text { incentives; However, respondents perceived CEO } \\
\text { pay to be tied to firm performance. }\end{array}$ & $\checkmark$ & & & $\begin{array}{l}\checkmark \\
\times\end{array}$ & & & & & & $\begin{array}{l}\checkmark \\
\times\end{array}$ & & $\begin{array}{l}\checkmark \\
\times\end{array}$ & \\
\hline O’Neill (2007) & $\begin{array}{l}\text { Interviews with an } \\
\text { undisclosed number of } \\
\text { non-executives directors } \\
\text { from large Australian } \\
\text { companies. }\end{array}$ & $\begin{array}{l}\text { The interviewees expressed concern about the level } \\
\text { of CEO pay; directors' perceptions of stakeholders' } \\
\text { views on CEO pay act as a constraint. }\end{array}$ & $\checkmark$ & & & $\checkmark$ & & & & & & $\checkmark$ & & & \\
\hline Main et al. (2008) & $\begin{array}{l}\text { Interviews (2006) with } \\
22 \text { directors, who serve } \\
\text { on remuneration } \\
\text { committees, of large UK } \\
\text { companies. }\end{array}$ & $\begin{array}{l}\text { The directors believed that executives are motivated } \\
\text { by a range of factors; that shareholders (and their } \\
\text { representatives, e.g. ABI) act as a constraint on pay; } \\
\text { and that selecting EPS and TSR as performance } \\
\text { measures was an act of conformance. }\end{array}$ & $\checkmark$ & & & $\checkmark$ & & & & & $\begin{array}{l}\checkmark \\
\times\end{array}$ & $\checkmark$ & $\checkmark$ & $\checkmark$ & \\
\hline $\begin{array}{l}\text { Ogden and } \\
\text { Watson (2008) }\end{array}$ & $\begin{array}{l}\text { Interviews }(2004-2006) \\
\text { with } 13 \text { non-executive } \\
\text { directors, } 4 \text { CEOs, } 7 \\
\text { senior managers (who } \\
\text { support the remuneration } \\
\text { committee) and } 2\end{array}$ & $\begin{array}{l}\text { In designing LTIPs, remuneration committees were } \\
\text { concerned about the legitimacy of their plans in the } \\
\text { eyes of shareholders and the extent to which the } \\
\text { plans motivated executives. }\end{array}$ & & & & $\checkmark$ & & & $\checkmark$ & & $\checkmark$ & & & & \\
\hline
\end{tabular}

Page 47 


\begin{tabular}{|c|c|c|c|c|c|c|c|c|c|c|c|c|c|c|c|c|}
\hline & consultants. & & & & & & & & & & & & & & & \\
\hline $\begin{array}{l}\text { Faulconbridge et } \\
\text { al. (2009) }\end{array}$ & $\begin{array}{ll}\text { Interviews } & \text { with } 50 \\
\text { recruitment } & \text { consultants } \\
\text { from Europe. } & \\
\end{array}$ & $\begin{array}{l}\text { Consultants are the key intermediary in the } \\
\text { executive labour market. }\end{array}$ & & & & & & & & & & & & & & \\
\hline Kovacevic (2009) & $\begin{array}{lcr}\text { Interviews } & \text { with } 14 \text { non- } \\
\text { executive directors, } 6 \\
\text { executives and } 2 \\
\text { consultants. }\end{array}$ & $\begin{array}{l}\text { Some interviewees believed that disclosure } \\
\text { regulation has resulted in increasing levels of } \\
\text { executive remuneration; not all interviewees agreed, } \\
\text { viewing transparency as necessary. }\end{array}$ & $\checkmark$ & & & & & & & & & & & & & $\begin{array}{l}\checkmark \\
\times\end{array}$ \\
\hline Bart et al. $(2011)^{c}$ & $\begin{array}{l}\text { Survey of } 47 \text { non- } \\
\text { executive directors of } \\
\text { Canadian public service } \\
\text { organisations. }\end{array}$ & $\begin{array}{l}\text { Directors asked to rate the importance of } 24 \\
\text { questions related to CEO pay; market } \\
\text { considerations, performance measurement, } \\
\text { independent and transparency were rated as } \\
\text { important ( }>5 \text { on a } 1-7 \text { scale). }\end{array}$ & $\checkmark$ & & & $\checkmark$ & & & & & & & & $\checkmark$ & $\checkmark$ & $\checkmark$ \\
\hline Bender (2011a) & $\begin{array}{l}\text { Interviews (2001-2003) } \\
\text { with } 30 \text { directors and } \\
\text { executives from } 5 \text { large } \\
\text { UK companies as well as } \\
5 \text { of their consultants. }\end{array}$ & $\begin{array}{l}\text { Remuneration consultants provide data about the } \\
\text { market, enhance the independence of the } \\
\text { remuneration committee, advice on best practice, } \\
\text { liaise with institutional investors, and enhance } \\
\text { organisational legitimacy. }\end{array}$ & $\checkmark$ & & & & & & & & & & $\checkmark$ & $\checkmark$ & $\begin{array}{l}\checkmark \\
x\end{array}$ & \\
\hline Bender (2011b) & $\begin{array}{l}\text { Interviews (2001-2003) } \\
\text { with } 30 \text { directors and } \\
\text { executives from } 5 \text { large } \\
\text { UK companies as well as } \\
5 \text { of their consultants. }\end{array}$ & $\begin{array}{l}\text { The author highlights the difficulties remuneration } \\
\text { committees face in trying to meet the expectations } \\
\text { set out in corporate governance codes and that the } \\
\text { executive labour market is a fiction. }\end{array}$ & $\checkmark$ & & & $\checkmark$ & & & & & & & & $x$ & & \\
\hline $\begin{array}{l}\text { Chapman and } \\
\text { Kelliher (2011) }\end{array}$ & $\begin{array}{lll}\text { Interviews } & \text { with } & 10 \\
\text { consultants. } & & \end{array}$ & $\begin{array}{l}\text { Studied consultants' opinions on the determinants } \\
\text { of reward mix in firms at all levels; market trends } \\
\text { were most influential. }\end{array}$ & $\checkmark$ & $\checkmark$ & & & & & & & & $\checkmark$ & $\checkmark$ & & $\checkmark$ & \\
\hline Main et al. (2011) & $\begin{array}{l}\text { Interviews with } 15 \text { chairs } \\
\text { of remuneration } \\
\text { committees from large } \\
\text { UK companies. }\end{array}$ & $\begin{array}{l}\text { Remuneration committees negotiate with } \\
\text { executives, shareholders and others, but tend to } \\
\text { settle on the market and regulatory norms; } \\
\text { Executives use pay as a scorecard. }\end{array}$ & $\checkmark$ & $\checkmark$ & & & & & $\begin{array}{l}\checkmark \\
x\end{array}$ & & $\checkmark$ & & $\begin{array}{l}\checkmark \\
\times\end{array}$ & $\checkmark$ & $\checkmark$ & \\
\hline $\begin{array}{l}\text { Aureli } \\
\text { and } \\
(2012)\end{array}$ & $\begin{array}{l}\text { Interviews with an } \\
\text { undisclosed number of } \\
\text { risk and human resource } \\
\text { managers from } 4 \text { Italian } \\
\text { companies. }\end{array}$ & $\begin{array}{l}\text { Studied the extent to which performance measures - } \\
\text { on which incentives were dependent - were } \\
\text { explicitly linked to risk management; interviewees } \\
\text { believed that there should be a link. }\end{array}$ & & & & $\checkmark$ & $\checkmark$ & $\checkmark$ & & & & & & & & \\
\hline $\begin{array}{l}\text { Hermanson et al. } \\
\text { (2012) }\end{array}$ & $\begin{array}{l}\text { Interviews with } 20 \text { non- } \\
\text { executive directors from } \\
\text { large US companies. }\end{array}$ & $\begin{array}{l}\text { Interviewees emphasised tension between } \\
\text { attracting, motivating and retaining executives and } \\
\text { overpaying executives in the eyes of shareholders }\end{array}$ & $x$ & $\checkmark$ & $\begin{array}{l}\checkmark \\
x\end{array}$ & $\checkmark$ & $\checkmark$ & & $\checkmark$ & $\checkmark$ & $\checkmark$ & & $\begin{array}{l}\checkmark \\
x\end{array}$ & $\checkmark$ & $\begin{array}{l}\checkmark \\
x\end{array}$ & \\
\hline
\end{tabular}




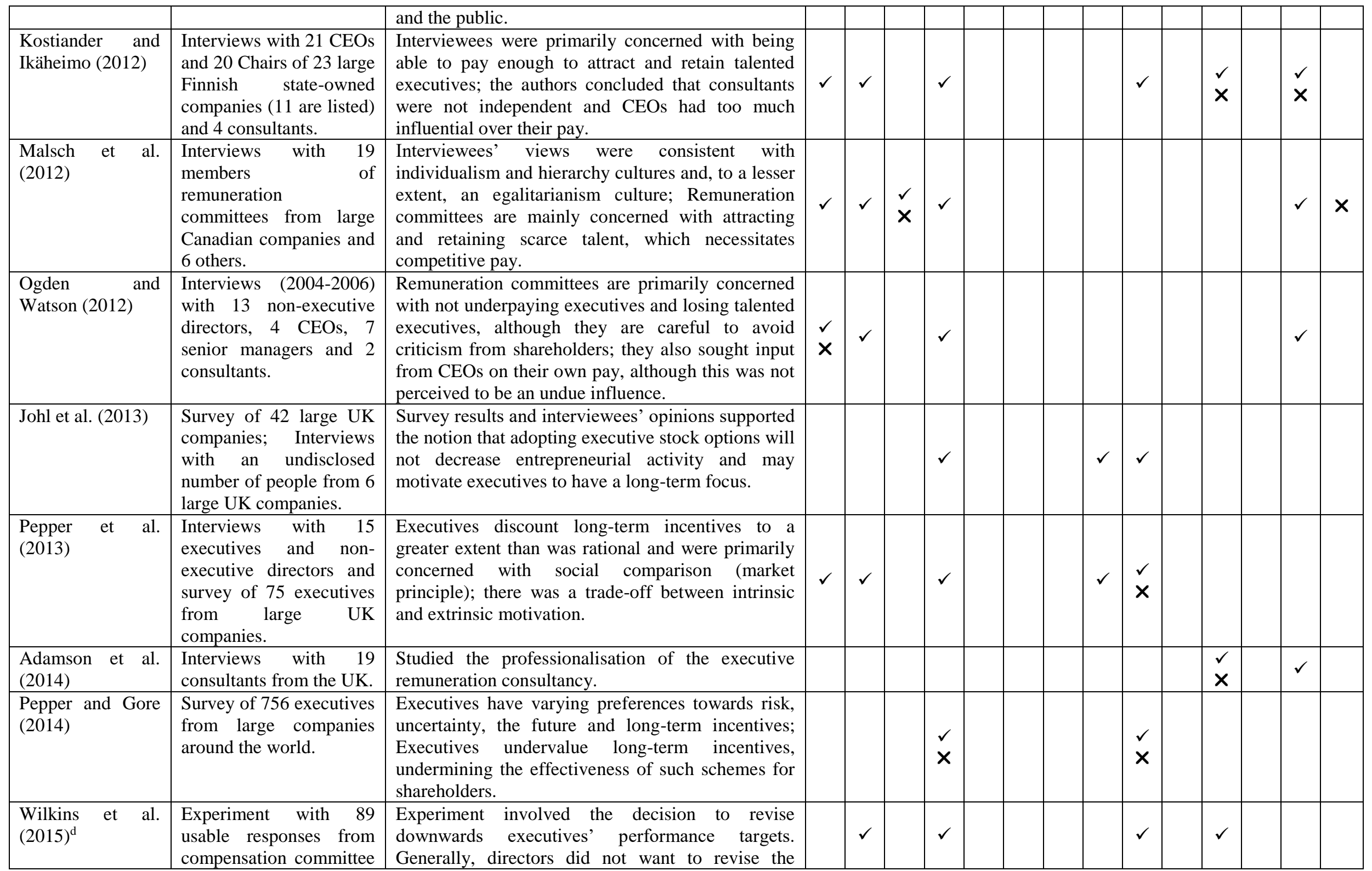

Page 49 


\section{Executive Remuneration Principles, Practices and Processes}

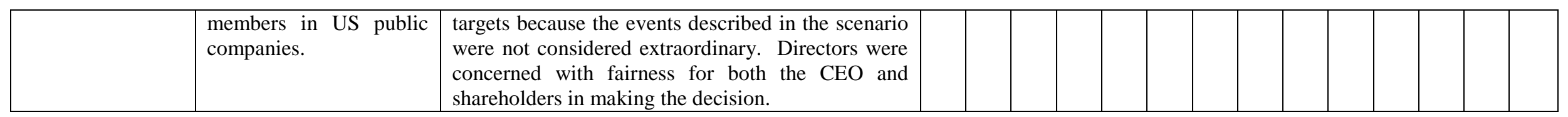

